\title{
Myrsine (Myrsinoideae- Primulaceae) no sudeste e sul do Brasil ${ }^{1}$
}

\author{
Myrsine (Myrsinoideae- Primulaceae) in Southeastern and Southern Brazil
}

\author{
Maria de Fátima Freitas ${ }^{2,4}$ \& Luiza Sumiko Kinoshita ${ }^{3}$
}

\begin{abstract}
Resumo
Este trabalho consiste no tratamento taxonômico das espécies do gênero Myrsine, Primulaceae, que ocorrem nas regiões sudeste e sul do Brasil, considerando também todas as espécies descritas em Rapanea, tratado aqui como sinônimo. O gênero é representado por arbustos e árvores dióicos com inflorescência umbeliforme e frutos globosos, drupáceos. Foram realizadas análises de materiais provenientes de herbários nacionais e estrangeiros, e expedições para coleta dos espécimes. Para identificação das 23 espécies de Myrsine são apresentados chave analítica, descrições, notas sobre a distribuição geográfica e ilustrações.

Palavras chave: Ericales, Myrsinaceae, Taxonomia.
\end{abstract}

\begin{abstract}
This work consists of the taxonomic treatment of Myrsine, Primulaceae, from the southeastern and southern regions of Brazil. All species described as Rapanea. are treated here as Myrsine. since the former has been placed in the synonymy with the latter. The genus is represented by dioecious shrubs and trees, with umbelliform inflorescences and globose, drupaceous fruits. Analysis of materials from herbaria and expeditions to collect specimens were performed. Analytical key, descriptions, notes on geographic distribution and illustrations are presented to identify the twenty three species of Myrsine found in the studied area.
\end{abstract}

Key words: Ericales, Myrsinaceae, Taxonomy.

\section{Introdução}

Myrsine L. pertence à família Primulaceae, subfamília Myrsinoideae, e apresenta cerca de 300 espécies com distribuição pantropical (Ricketson \& Pipoly 1997; Ståhl \& Anderberg 2004). No Brasil, as espécies desse gênero são conhecidas popularmente como "caapororoca", "capororoca" e "pororoca". A madeira é utilizada especialmente como combustível, também como matéria para extração de tanino e estacas na construção civil (Smith \& Downs 1957). Lorenzi (1992) mencionou o uso da madeira de Myrsine coriacea (Sw.)R. Br. ex Roem. \& Schult. e M. guianensis (Aubl.) O. Kuntze na construção civil e como lenha e carvão, e de M. parvifolia A. DC. "para confecção de brinquedos, miolo de portas e painéis..."(Lorenzi 2009). As folhas são utilizadas como tintoriais
(Siqueira 1987), e os frutos são fonte alimentícia para várias espécies de pássaros (Pineschi 1990).

Estudos que se referem às espécies brasileiras de Myrsine (ou Rapanea) são os de Edwall (1905), Augusto (1946), Smith \& Downs (1957), Joly \& Jung (1978), Jung (1981), Lundell (1984), Siqueira (1987,1993), Fonnegra-Gómez \& JungMendaçolli (1985), Jung-Mendaçolli \& Bernacci (1997a,1997b,1997c, 2000, 2001), Harvey \& Pipoly (1995), Otegui (1998), Ricketson \& Pipoly (1999), Jung-Mendaçolli et al. (2005), JungMendaçolli (2009), Freitas (2003, 2012) e Freitas \& Carrijo (2008, 2009a, 2009b, 2012, 2014a, 2014b), Freitas \& Kinoshita $(2004,2005)$ e Freitas et al. (2009, 2010).

O presente trabalho trata do estudo das espécies de Myrsine ocorrentes no sudeste e sul

\footnotetext{
Parte da tese de doutorado da primeira autora.

${ }^{2}$ Instituto de Pesquisas Jardim Botânico do Rio de Janeiro, Diretoria de Pesquisas, R.Pacheco Leão, 915, 22460-030, Jardim Botânico, Rio de Janeiro, RJ, Brasil.

${ }^{3}$ Universidade Estadual de Campinas, Depto. Biologia Vegetal, Cidade Universitária Zeferino Vaz, R. Monteiro Lobato, 255, 13083-862, Campinas, São Paulo, SP, Brasil.

${ }^{4}$ Autor para correspondência: ffreitas@jbrj.gov.br
} 
do Brasil, considerando-se sua maior diversidade nestas regiões. São apresentadas descrições que ampliam as informações de espécies só conhecidas pelas obras originais e corroboram com a ampla circunscrição do gênero Myrsine, que inclui Rapanea Aubl. como sinônimo, bem como chaves de identificação, ilustrações, comentários e sdistribuição geográfica.

\section{Material e métodos}

Iniciou-se esse estudo com o levantamento dos táxons dos gêneros Myrsine e Rapanea, que foram descritos para o Brasil, como base nas obras de De Candolle (1834, 1837, 1841a, 1841b, 1844), Miquel (1856) e Mez (1902). Estas obras foram utilizadas para a identificação das espécies que foram coletadas na região de estudo ou em análises dos espécimes provenientes de coleções de herbários brasileiros e internacionais com acrônimos citados nos materiais selecionados, segundo Thiers (continuously updated). São citados os basiônimos e seus respectivos exemplares-tipo para cada táxon estudado.

Todo material coletado para este trabalho foi depositado nos Herbários da Universidade Estadual de Campinas (UEC), do Jardim Botânico do Rio de Janeiro (RB), da Universidade Estadual de Londrina (FUEL) e do Instituto Agronômico de Campinas (IAC). O diâmetro dos ramos terminais foi medido em ramos secos. A dimensão das folhas foi obtida em folhas secas adultas, do terceiro ou quarto nós em diante, sendo apresentados os valores mínimos e máximos e as variações encontradas. As ilustrações foram baseadas em material herborizado e as dimensões das partes reprodutivas nas pranchas foram ampliadas dez vezes ao seu tamanho original.

\section{Resultado}

Tratamento taxonômico

Myrsine L., Sp. P1. 1: 196.1753.

Arbustos ou arvoretas com estruturas secretoras internas globóides ou lineares nas folhas, flores e frutos; ramos pilosos ou glabros. Folhas alternas, pecioladas ou sésseis, com tricomas glandulares. Inflorescências umbeliformes ou pequenos racemos, dispostas nos ramos terminais, pedúnculo com brácteas pilosas; multifloras. Flores unissexuadas, pedicelos glabros ou pilosos, bractéola única, actinomorfas, diclamídias, 4-5 (6) lobos obtusos ou arredondados, margem pilosa; androceu isostêmone, com estames ou estaminódios inseridos na base do tubo da corola ou sobre os lacínios, filetes livres ou conatos na base formando um pequeno tubo estaminal, este tubo com ou sem apêndices alternos aos filetes; anteras rimosas; conectivo com ou sem cavidades com secreção escura; ovário e pistilódio globosos, uniloculares; placentação central, globosa, óvulos imersos ou visíveis através de poros na placenta; estilete geralmente ausente; estigma cônico, 3-lobado. Frutos globosos a elípticos, drupáceos com o endocarpo esclerificado; semente globosa, única, com testa fina, restos da placenta persistentes; endosperma ósseo, liso ou ruminado; embrião reto com eixo longo, cilíndrico, transversais às sementes, e cotilédones foliáceos reduzidos.

Myrsine foi descrito por Linnaeus (1753), cuja posição taxonômica oscilou dentro das tribos designadas para a família Myrsinaceae, sendo atualmente considerado pertencente à subfamília Myrsinoideae (Stevens 2001), família Primulaceae.

Aublet (1775) descreveu o gênero Rapanea, que foi sinonimizado em Myrsine L. por De Candolle (1834), cujo nome foi aceito por Miquel (1856) na Flora Brasiliensis. Mez (1902) revalidou Rapanea, diferenciando-o pelo fato dos filetes estarem completamente fundidos à corola, ao passo que em Myrsine, o tubo estaminal está parcialmente livre, de acordo com o conhecimento desta época. Mez (1902) também utilizou como critério de diferenciação entre estes dois gêneros a presença ou ausência de um curto estilete, porém, nas descrições das espécies, quando descreveu o gineceu, não se referiu a este caráter de forma clara. Durante quase todo o século XX, diversos trabalhos foram publicados discutindo a revalidação de Rapanea (Pipoly 1996).

No estudo de espécies americanas, como os de Lundell (1966,1971), para a Guatemala e Panamá, de Burkart (1979) e Macbride (1959) para Argentina e Peru, respectivamente, esses autores seguiram a obra de Mez (1902). Mais tarde Lundell (1981,1984) aceitou Myrsine seguindo Stearn (1969), que foi o primero autor, após Mez (1902), a considerar este gênero para as espécies americanas.

Smith $(1973,1981)$ justificou o uso de Rapanea pelo fato das espécies por ele analisadas não apresentarem parte do tubo estaminal livre, como em Myrsine africana L. (Mez1902). Sleumer (1986) também seguiu este autor ao adotar Rapanea na revisão das espécies da Nova Guiné.

Fosberg \& Sachet $(1975,1980)$ adotaram o conceito de Myrsine, sugerindo que as diferenças 
encontradas no androceu podem ser apresentadas em níveis de seções dentro deste gênero. A partir daí, estudos como os de Wagner et al. (1990 apud Pipoly 1996), Pipoly (1991, 1992a, 1992b,1996), Harvey \& Pipoly (1995), Otegui (1998), Ricketson \& Pipoly (1999), Valdés (2000, 2002), Jackes (2005) e Ricketson (2013) têm considerado as espécies de Rapanea como Myrsine. Exceto no Brasil, Jung (1981), Siqueira (1987, 1993), Jung-Mendaçolli (2009) e Jung-Mendaçolli \& Bernacci (1997a 1997b, 1997c, 2001), Jung-Mendaçolli et al . (2005), continuaram adotando Mez (1902).

Na Flora Brasiliensis, Miquel (1856) redescreveu as espécies de De Candolle (1837, 1844) e de Martius (1841). Das 13 espécies descritas por Miquel (1856), 12 ocorrem no sudeste e sul do Brasil, exceto Myrsine schomburgkiana Miq.

Após a obra de Mez (1902), foram descritas três novas espécie deste gênero para o Brasil: Myrsine altomontana M.F.Freitas \& Kin.-Gouv., Myrsine rubra M.F.Freitas \& Kin.-Gouv., e Rapanea hermogenesii Jung-Mendaçolli \& Bernacci, cujo táxon já foi combinado em Myrsine (Freitas \& Kinoshita 2005). Até o presente são registradas 23 espécies de Myrsine para as regiões sudeste e sul e 26 espécies para a Flora Brasileira como um todo (Freitas et al. 2014), porém este número pode ser elevado após uma ampliação dos estudos e coletas nas Regiões Norte e Nordeste do Brasil.

\section{Chave para identificação das espécies de Myrsine do sudeste e sul do Brasil}

1. Ramos terminais pilosos, com tricomas em toda a sua extensão................................................. 2

1'. Ramos terminais glabros ou com tricomas nas gemas apicais....................................................5

2. Árvores e arvoretas de (2)4-10(20)m alt, ramos e limbo foliar cobertos por pelos ramificados; ocorrem em diversos ambientes e localidades, em áreas abertas, orlas de mata e estradas

5. Myrsine coriacea

2'. Arbustos 1-4 m alt., ramos e limbo foliar cobertos por tricomas não ramificados; ocorrem em serras de Minas Gerais, Rio de Janeiro e São Paulo

3. Tricomas afilados, cobrindo todo o ramo, limbo foliar e flores ...... 23. Myrsine villosissima

3. Tricomas não afilados, cobrindo a nervura principal e/ou dispersos no limbo foliar, e flores somente com tricomas capitados.

4. Ramos terminais $1,5 \mathrm{~mm}$ diam., folhas ovadas a obovadas com base ovada o ápice agudo a arredondado, 3-5 cm de compr., 2-3 cm larg., pecíolo 2-3mm compr....

8. Myrsine glazioviana

4'. Ramos terminais $2 \mathrm{~mm}$ diam., folhas pequenas, ovadas a elípticas com a base cordada e o ápice agudo a arredondado, 1,5-2 cm compr., $1 \mathrm{~cm}$ larg.; pecíolo $1 \mathrm{~mm}$ compr......

5'. Folhas jovens e adultas com o limbo sempre dotado de linhas.

4. Myrsine congesta

Folhas jovens com linhas raras, dispersas no limbo ou não visívei....................... 6

6. Linhas translúcidas, densas e sempre visíveis em todas folhas jovens e adultas

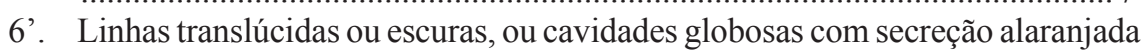
ou enegrecida, esparsas e visíveis apenas em folhas jovens ....................... 8

7. Folhas membranáceas a cartáceas com cavidades secretoras oblíquas, lanceoladas, ápice e base agudos, 6 a 10 flores por inflorescência, bractéolas 1-1,2 mm compr ..................................14. Myrsine lineata

7'. Folhas coriáceas, obovadas a elípticas, base sempre aguda e ápice agudoacuminado ou arredondado; 10 a 12 flores por inflorescência, bractéolas $0,5 \mathrm{~mm}$ compr. 22. Myrsine venosa

8. Linhas translúcidas na nervura principal de folhas adultas, e no limbo de folhas jovens, frutos elípticos de 7-9 mm compr

10. Myrsine hermogenesii

8'. Linhas translúcidas somente no limbo, não visíveis na nervura principal de todas as folhas, frutos globosos ou elípticos de 3-7 mm compr. 
9. Árvores com casca interna vermelha escura, frutos elípticos, pedicelos $0,5-1 \mathrm{~mm}$ compr.

19. Myrsine rubra

9'. Arbustos com folhas congestas, ramos contorcidos a árvores com casca interna vermelho claro ou amarelada, frutos globosos, pedicelos 1-5 $\mathrm{mm}$ compr 10

10. Plantas robustas, folhas 6-15(30) cm compr., linhas translúcidas nas folhas jovens e adultas, cavidades globosas não visíveis ou ausentes

10'. Plantas delgadas, folhas 2-5(9) cm compr., sem linhas translúcidas, cavidades arredondadas com conteúdo escuro ou alaranjado nas folhas jovens e adultas

11. Ramos terminais com 5-7 mm diam., nervura central na base foliar com 1,5-2 mm larg.....

9. Myrsine guianensis

11'. Ramos terminais com 1-4 mm diam., nervura central na base foliar com $1 \mathrm{~mm}$ larg........ 12

12. Casca interna vermelha, ramos terminais $1 \mathrm{~mm}$ diam., pecíolos avermelhados, flores 3-4 mm compr

7 Myrsine gardneriana

12'. Casca interna amarelada, ramos terminais 3-4 mm diam., pecíolos alvo-esverdeados, flores $5-7 \mathrm{~mm}$ compr

13. Inflorescências densas nos ramos, 10 a 15 flores, pedicelos $3-5 \mathrm{~mm}$ compr., frutos 4-5mm compr 21. Myrsine umbellata

13'. Inflorescências esparsas nos ramos, 5-8 flores, pedicelos 1,5-2 mm compr., frutos 3-4 mm compr 13. M. leuconeura

14. Folhas membranáceas a cartáceas, $2-5(9) \mathrm{cm}$ compr., acinzentadas e delicadas quando desidratadas, inflorescências esparsas nos ramos, pedicelos maiores que $1 \mathrm{~mm}$ 15

14'. Folhas cartáceas a coriáceas, $2,5-4,5 \mathrm{~cm}$ compr., congestas no ápice dos ramos, inflorescências densas, pedicelos menores que $1 \mathrm{~mm}$ compr. 16

15. Folhas ovado-lanceoladas, pecíolos $4-5 \mathrm{~mm}$ compr., flores tetrâmeras, pedicelos ca $1,5 \mathrm{~mm}$ compr. 15. Myrsine loefgrenii

15'. Folhas elíptico-lanceoladas, pecíolos 5-7 mm compr., flores pentâmeras, pedicelos $2,5-4 \mathrm{~mm}$ compr 18. Myrsine parvula

16. Folhas jovens sem cavidades globosas, com linhas translúcidas, ramos terminais $1-2 \mathrm{~mm}$ diam 1. Myrsine altomontana

16'. Folhas jovens e adultas com cavidades globosas, sem linhas translúcidas, ramos terminais 2-4 mm diam

17. Plantas com $1-2 \mathrm{~m}$ alt., ramos terminais $2-4 \mathrm{~mm}$ diam., não contorcidos folhas elípticas a lineares, pecíolo $2-4 \mathrm{~mm}$ compr., inflorescência séssil, 6-7 flores, pedicelos 0,6-1 $\mathrm{mm}$ compr..... 20. Myrsine squarrosa

17'. Plantas com menos de $1 \mathrm{~m}$ alt., ramos terminais até $2 \mathrm{~mm}$ diam., contorcidos; folhas ovadas a elípticas, pecíolo $1 \mathrm{~mm}$ compr., pedúnculo da inflorescência com $1 \mathrm{~mm}$ compr., 4-5 flores, pedicelos $0,3-0,5 \mathrm{~mm}$ compr.

3. Myrsine cipoensis

18. Folhas com ápice emarginado .19

18'. Folhas com ápice agudo a arredondado.................2 20

19. Folhas obovadas, $2,5-5 \mathrm{~cm}$ compr.; inflorescências com 5-7 flores; ocorre em restinga 17. Myrsine parvifolia

19'. Folhas ovadas a elípticas, $(2) 3-4(6,5) \mathrm{cm}$ compr., inflorescências com 4-6 flores; ocorre em campos rupestres de Minas Gerais 
20. Folhas espatuladas; pedúnculo da inflorescência com 5-10(30) mm compr, formando pequenos racemos; ocorre somente na região sul. 11. Myrsine laetevirens

20'. Folhas ovadas a elípticas; pedúnculo da inflorescência com até $5 \mathrm{~mm}$ compr, umbeliformes, ocorrem no sudeste e sul

21. Tronco e ramos com súber espesso, fissurado; pecíolos $0,3-0,5 \mathrm{~cm}$ compr., flores estaminadas com apêndices alternos aos lobos da corola, ocorre no cerrado e em campos rupestres

16. Myrsine monticola

21'. Tronco e ramos com súber pouco espesso, liso; pecíolos $0,5-1,2 \mathrm{~cm}$ compr., flores sem apêndices alternos aos lobos da corola

22. Arvoretas 4-6m alt., ramos 3,5 mm diam., folhas espatuladas a elípticas, linhas não visíveis nas flores e frutos, pedicelos do fruto $2-3 \mathrm{~mm}$ compr. 2. Myrsine balansae

22'. Arvoretas ou arbustos $2-4 \mathrm{~m}$ alt., ramos $2,5 \mathrm{~mm}$ diam., folhas estreitamente lanceoladas, linhas visíveis em flores e frutos, pedicelos do fruto 1,5-2 mm compr.

12. Myrsine lancifolia

1. Myrsine altomontana M.F.Freitas \& Kin.Gouv. Rodriguésia 56(87): 68.2005. Tipo: Brasil, Paraná: Quatro Barras, Morro Sete, 1200 m.s.m., 6.VI.1989, fl., O.S. Ribas et al. 120 (holótipo, $\mathrm{MBM}$; isótipo, $\mathrm{RB}$ ).

Arbusto $(0,6)-2 \mathrm{~m}$ alt., ramos terminais $1-2$ $\mathrm{mm}$ diâmetro, glabros. Folhas cartáceas a coriáceas, congestas no ápice dos ramos, glabras, ovadas a elípticas, ápice agudo a acuminado, base aguda, 2,5-3,5 cm compr., 1-1,5 cm larg., margem inteira, levemente revoluta, nervura principal proeminente em ambas as faces, na face inferior com $0,8 \mathrm{~mm}$ largura na base foliar, folhas jovens com linhas translúcidas, nervuras secundárias evidentes apenas no material seco; pecíolo alvo-esverdeado, (2)35 (8) mm compr. Inflorescências com pedúnculo curto, 0,5-1 mm compr., 5-8 flores; bractéolas 1 $\mathrm{mm}$ compr., triangulares, tricomas curtos. Flores pentâmeras, 3-4 mm compr.; pedicelos 0,8-1 mm compr.; sépalas $0,5-1 \mathrm{~mm}$ compr., triangulares, tricomas curtos, esparsos e raros, cavidades secretoras globosas; pétalas 1,8-2 mm compr., 1 $\mathrm{mm}$ larg., cavidades secretoras elípticas e lineares em maior densidade que as globosas; estames 1-1,2 mm compr, estaminódios $0,8-1 \mathrm{~mm}$ compr., filetes conatos, apêndices do tubo estaminal presentes; ovário e pistilódio globosos $1 \mathrm{~mm}$ compr. e $1 \mathrm{~mm}$ de larg.; estigma ca. 0,5 mm. Fruto globoso, 3-4 mm compr., 2,5-3 mm larg., pericarpo do fruto imaturo verde, denso em cavidades com secreção escura.

Myrsine altomontana assemelha-se a $M$. squarrosa por apresentar folhas glabras, porém suas folhas são ovadas a elípticas, ápice agudo e podem apresentar linhas translúcidas nas folhas jovens. Ocorre geralmente em florestas de altitude do estado do Paraná e Santa Catarina, com uma ocorrência registrada para o Pico do Cardoso. Ilustração em Freitas \& Kinoshita (2005).

Material selecionado: PARANÁ, Guaratuba, Serra de Araçatuba, 26.VII.1997, O.S. Ribas et al. 1930 (MBM). SANTA CATARINA, Mun. São Joaquim, Serra do Oratório, IV.1967, J. Mattos 14574 (HAS, RB, UEC). SÃO PAULO, Mun. Cananéia, Ilha do Cardoso, Pico do Cardoso, ca. $840 \mathrm{msm}, 5 . X I I .1990, F$ Barros et al. 2078 (SP, IAC).

2. Myrsine balansae (Mez) Otegui, Candollea 53: 155.1998. Rapanea balansae Mez in Engl. Pflanzenr. 9(IV.236): 391.1902. Tipo: Paraguai, Paraguari, 24.IX.1874, Balansa 2379 (holótipo, G)

Fig. 1a-d

Arvoretas 4-6 m alt., ramos terminais ca. 3,5 mm diam., não suberoso, robustos, sem fendas, glabros. Folhas membranáceas a cartáceas, glabras, lisas, ovadas a elípticas, ápice agudo a arredondado, base aguda, revoluta na face abaxial, (11)13-14,5(15) cm compr., 3,5-4,5(5) cm larg., margem inteira, levemente revoluta, nervura principal proeminente em ambas as faces, na face inferior com $1 \mathrm{~mm}$ largura na base foliar, linhas translúcidas não visíveis, raro em folhas jovens, nervuras secundárias evidentes apenas no material desidratado; pecíolo alvo-esverdeado, (5)7-10(12) $\mathrm{mm}$ compr. Inflorescências com pedúnculo curto, 1-2 mm compr.; bractéolas $2-3 \mathrm{~mm}$ compr., triangulares a lanceoladas, margem ciliada. Flores pentâmeras, 4-5 mm compr.; pedicelos 1-1,5mm compr.; sépalas $1 \mathrm{~mm}$ compr., triangulares, tricomas curtos, raros, quase glabras, cavidades secretoras não visíveis; pétalas 3-3,2 mm compr., $1 \mathrm{~mm}$ larg., cavidades secretoras não visíveis, estames $2 \mathrm{~mm}$ compr., sem secreção, estaminódios $1 \mathrm{~mm}$ compr., filetes conatos, apêndices do tubo 
estaminal ausentes; ovário cônico 1-1,2 mm compr e $1 \mathrm{~mm}$ de larg., pistilódio cônico 1-1,4 mm compr.; estigma $3 \mathrm{~mm}$. Fruto elipsóide a globoso, $5 \mathrm{~mm}$ compr., $4 \mathrm{~mm}$ larg., pedicelo 2-3 $\mathrm{mm}$, pericarpo do fruto imaturo verde, cavidades secretoras pouco visíveis.

Espécie muito semelhante a M. umbellata, porém seus ramos terminais são mais robustos. Nos materiais analisados as cavidades secretoras não foram vistas com frequência no limbo foliar e não visualizados nos elementos reprodutivos. Por apresentarem ramos terminais mais robustos e pedicelos florais mais curtos que os de $M$. umbellata, também assemelha-se a $M$. guianensis. Porém, os frutos são elipsóides e as folhas tornam-se avermelhadas ou com nuances róseas após dessecação. Esta espécie foi descrita por Mez (1902), como Rapanea balansae, tendo como localidade típica o Paraguai. Otegui(1998) a transferiu para Myrsine mencionando, pela primeira vez, sua ocorrência também na Argentina e no estado do Paraná. Este trabalho registra sua ocorrência em São Paulo, Minas Gerais e Rio de Janeiro.

Material selecionado: MINAS GERAIS: Passa Quatro, 3.V.1948, A.C. Brade et al. 19080 (RB). PARANÁ: Londrina, Faz. Sta. Helena, 8.V.1986, L.N. Pizzaia 60 (FUEL, RB); Mauá da Serra, Sítio Xaxim 2, 15.XII.1999, fr., M.F. Freitas 297, 298 (FUEL, UEC). Reserva, estrada para Reserva, 26.VIII.1997, M.R.C. Paiva et al. (FUEL 24545, UEC). RIO DE JANEIRO: Teresópolis, Granja Mafra, 28.V.1977, L.F. Carvalho (RB 189138). SÃO PAULO: Monte Alegre do Sul, Est. Exp. IAC, 19.V.2000, S.L. Jung-Mendaçolli et al. 1074, 1075 (IAC).

3. Myrsine cipoensis M.F.Freitas \& Kin.-Gouv., Rodriguésia 56(87): 68.2005. Tipo: Brasil; Minas Gerais: Santana do Riacho, Serra do Cipó, km 125da Rodovia Belo Horizonte - Conceição do Mato Dentro, Córrego da Cachoeirinha, ao lado da estátua do Velho Juca, 7.XII.1991, fl., J.R. Pirani et al. CFSC 12822 (holótipo, SPF; isótipo, RB).

Arbustos 0,70 m alt., ramos terminais ca. $2 \mathrm{~mm}$ diâmetro, glabros, contorcidos. Folhas coriáceas, congestas no ápice dos ramos, glabras, lisas, ovadas a elípticas, ápice agudo, base arredondada, revoluta, 2,5-4,5 cm compr., 1,3-1,5 $\mathrm{cm}$ larg., margem inteira, levemente revoluta, nervura principal proeminente em ambas as faces, na face inferior com $1 \mathrm{~mm}$ largura na base foliar, cavidades secretoras com conteúdo escuro, evidentes em folhas jovens e adultas, nervuras secundárias evidentes no material seco; sésseis.
Inflorescências com pedúnculo ca. $1 \mathrm{~mm}$ compr., 4-5 flores, bractéolas $1 \mathrm{~mm}$ compr., triangulares, tricomas curtos. Flores pistiladas pentâmeras, 2,5-3 mm compr.; pedicelos 0,3-0,5 mm compr.; sépalas $1 \mathrm{~mm}$ compr., triangulares, tricomas curtos, esparsos e raros, cavidades secretoras globosas; pétalas 1,5-2 mm compr., $1 \mathrm{~mm}$ larg., cavidades secretoras globosas, numerosas até a base da corola; estaminódios 0,8-1 mm compr., filetes conatos, apêndices do tubo estaminal ausentes; ovário globoso $1 \mathrm{~mm}$ compr e $1 \mathrm{~mm}$ de larg.; estigma 1 $\mathrm{mm}$. Flores estaminadas e frutos não vistos.

Myrsine cipoensis caracteriza-se por ser um arbusto pequeno, com ramos contorcidos e lenhosos, entrenós curtos e folhas congestas no ápice. É conhecida apenas pelo material-tipo, considerada uma espécie rara e endêmica da Serra do Cipó (Freitas \& Carrijo 2009a). Ilustração e espécime-tipo em Freitas \& Kinoshita (2005).

4. Myrsine congesta (Sw. ex Mez) Pipoly, Novon 2:407.1992. Rapanea congesta Schwacke ex Mez in Engl. Pflanz. 4. 236(9): 383.1902. Tipo: Brasil, Est. Minas Gerais: Serra de Ibitipoca, Schwacke 12384 (isosintipo, RB); Serra de Ouro Preto, Gomes 1273 (sintipo, M); Rio de Janeiro, Petrópolis, Morro Carangola, Glaziou 14044 (sintipo, $\mathrm{C}$; isosíntipos, $\mathrm{K}, \mathrm{R}$ )

Fig. 1e-h

Arbustos $(0,5) 1-1,5 \mathrm{~m}$ alt., ramos terminais $2 \mathrm{~mm}$ diâmetro, pilosos, ferrugíneos. Folhas coriáceas, pilosas, lisas, ovadas a elípticas, ápice agudo a arredondado, base cordada, 1,5-2 cm compr., 1,0 cm larg., margem levemente serreada, revoluta, nervura principal proeminente na face abaxial, com 0,3 mm largura na base foliar, linhas translúcidas não evidentes, nervuras secundárias evidentes apenas no material desidratado; pecíolo 1 mm compr., piloso. Inflorescências com pedúnculo curto, $1 \mathrm{~mm}$ compr.; bractéolas 1-1,5 mm compr., cavidades secretoras triangulares a ovóides, tricomas longos. Flores pentâmeras, 3,5-4 mm compr.; pedicelos 0,5-1 mm compr.; sépalas 1-2 $\mathrm{mm}$, ovóides, tricomas longos e densos, cavidades secretoras globosas; pétalas 2,5-3 mm compr., 1 mm larg., cavidades secretoras globosas e elípticas, raro lineares; estames e estaminódios 1-1,2 mm compr.; filetes conatos, apêndices do tubo estaminal ausentes; ovário globoso $1 \mathrm{~mm}$ compr e $1 \mathrm{~mm}$ larg, pistilódio cônico $0,8 \mathrm{~mm}$ compr.; estigma 1 $\mathrm{mm}$. Fruto globoso, 3-4 mm compr., 2-3 mm larg., pericarpo do fruto imaturo verde com cavidades secretoras pouco visíveis. 
Myrsine congesta pertence ao grupo das espécies pilosas. Suas folhas são muito coriáceas, de forma e pilosidade bastante variável como em $M$. coriacea. Dentre as espécies arbustivas destaca-se pelas folhas com base cordada e ocorre em campos rupestres de Minas Gerais. Foram observados poucos representantes coletados em campos de altitude do Rio de Janeiro.

Material selecionado: MINAS GERAIS: Ibitipoca, Serra de Ibitipoca, VIII.1896, Schwacke 3184 (OUPR); 13.V.1970, P. L. Krieger (CESJ 8643, RB 345697); Santana do Riacho, Serra do Cipó, 15.VIII.1979, A. M. Giulietti et al. CFSC 5629 (SPF, RB). RIO DE JANEIRO: Santa. Maria Madalena, Pedra do Desengano, 1800-1850msm, 28.VI.1989, G. Martinelli 13352 et al. (RB).

5. Myrsine coriacea (Sw.) R. Br. ex Roem. \& Schult., Syst. Veg. 4: 511.1819. Samara coriacea Sw., Prodr. 1: 32.1788. Tipo: Jamaica, s.local, s.d., O. Swartz s.n. (holótipo, BM; isótipo, L, S)

Fig. 1i-1

Árvores e arvoretas 4-10(20)m alt., ramos terminais $3 \mathrm{~mm}$ diâmetro, tricomas ferrugíneos e ramificados. Folhas membranáceas a cartáceas, pilosas, lisas, ovadas a lanceoladas, ápice agudo a acuminado, base aguda, revoluta na face abaxial, (3)6-8(10) cm compr., 1,5-2 cm larg., margem inteira, levemente revoluta, nervura principal proeminente em ambas as faces, na face inferior com $1 \mathrm{~mm}$ largura na base foliar, linhas translúcidas pouco evidentes em folhas jovens e adultas, nervuras secundárias evidentes apenas no material desidratado; pecíolo alvo-esverdeado, 5-10 mm compr. Inflorescências com pedúnculo curto, 1-2 mm compr.; 6-8 flores; bractéolas 0,7-1 mm compr., triangulares, tricomas curtos. Flores pentâmeras, 2-3,5 mm compr.; pedicelos 1-1,5 mm compr.; sépalas $0,5-0,8 \mathrm{~mm}$ compr., triangulares, tricomas curtos, esparsos, quase glabras, cavidades secretoras globosas; pétalas (1)2-2,5 mm compr., 1 $\mathrm{mm}$ larg., cavidades secretoras globosas e elípticas; estames $1-1,5 \mathrm{~mm}$ compr., estaminódios $0,8 \mathrm{~mm}$ compr.; filetes conatos, apêndices do tubo estaminal ausentes; ovário globoso $0,8-1 \mathrm{~mm}$ compr, $1 \mathrm{~mm}$ de larg; pistilódio cônico $1 \mathrm{~mm}$ compr.; estigma 1 $\mathrm{mm}$. Fruto globoso, 3-4 mm compr., $3 \mathrm{~mm}$ larg., pericarpo do fruto imaturo verde com cavidades secretoras visíveis.

Myrsine coriacea é popularmente conhecida como "capororoquinha", apresenta os ramos terminais cobertos por tricomas ferrugíneos, ramificados, porém a parte do ramo exposta ao sol apresenta coloração acinzentada e a inferior pode apresentar um tom ferrugíneo. A variação na pilosidade das folhas é comumente observada, sendo mais intensa em indivíduos que ocupam áreas de maiores altitudes.

Destaca-se das demais espécies de Myrsine pela sua ampla distribuição, ocorrendo nas diversas formações florestais do Brasil, principalmente em áreas abertas, secas e beira de estradas. É considerada espécie pioneira por ser dominante nas capoeiras e, devido a sua alta densidade forma os "Rapanietum" (região com dominância desta espécie, denominada por Klein [1980]) em certos estágios de sucessão secundária, sendo recomendada na recuperação de ambientes degradados. Esta terminologia foi atualizada por Siminski et al (2004) para "Myrsinietum" devido a alteração nomenclatural da espécie. Pode ser utilizada para a produção de lenha e carvão, alimentação de pássaros e arborização urbana, e seus frutos podem ser usados como condimentos (Carvalho 1994).

Material selecionado: ESPÍRITO SANTO: Ibiraçú, Est. Ecol. Morro da Vargen, 27.V.1990, J.M.L. Gomes et al. 1149 (MBML, VIES); MINAS GERAIS: Bom Jardim de Minas, 29.IX.1989, T.S.M. Grandi et al. 2609 (BHCB); PARANÁ: Tamarana, Faz. Prata, 15.XII.1999, M.F. Freitas et al. 300 (UEC, FUEL);RIO DE JANEIRO: Itatiaia, Pq. N. Itatiaia, trilha entre os abrigos Macieira e Macena, 8.XI.1993, R. Guedes et al. 2309 (RB); RIO GRANDE DO SUL: Pq. N. Aparatos da Serra, 23.VI.1980, J.L. Waechter 1621 (PEL); SANTA CATARINA: São José, Serra da Boa Vista, 700msm, 3.III.1961, Reitz \& Klein 10843 (HBR); SÃO PAULO: São José do Barreiro, 1900msm, 30.V.2000, L. Freitas et al. 868 (UEC);

6. Myrsine emarginella Miq. in Mart. Fl. Bras. 10: 312.1856. Tipo: Minas Gerais, Serra da Piedade, Claussen 146, 150 (síntipos, U) Fig. 1m-p

Arbustos $1 \mathrm{~m}$ alt., ramos terminais $2 \mathrm{~mm}$ diâmetro, glabros. Folhas membranáceas, glabras, lisas, ovadas a elípticas, ápice arredondado, emarginado, base aguda a arredondada, revoluta na face abaxial, (2)3-4(6,5) cm compr., $(0,8) 1-$ $1,5(1,8) \mathrm{cm}$ larg., margem inteira, nervura mediana proeminente na face abaxial e com $0,5 \mathrm{~mm}$ largura na base foliar, glândulas evidentes e cavidades secretoras não visíveis em folhas jovens e adultas, nervuras secundárias não evidentes em ambas as faces; pecíolo alvo-esverdeado, 1-2(3) $\mathrm{mm}$ compr. Inflorescências com pedúnculo curto, 1mm compr.; 4-6 flores, bractéolas $1 \mathrm{~mm}$ compr., triangulares, tricomas curtos, poucos; flores 
pentâmeras, 2,5-3 mm compr.; pedicelos 0,5-1 $\mathrm{mm}$ compr.; sépalas $1 \mathrm{~mm}$ compr., triangulares, tricomas curtos, esparsos, cavidades secretoras globosas com secreção escura; pétalas $2-2,5 \mathrm{~mm}$ compr., $1 \mathrm{~mm}$ larg., cavidades secretoras elípticas e lineares em maior densidade que globosas; estames $2 \mathrm{~mm}$ compr., secreção densa e escura ao longo do conectivo, estaminódio $1 \mathrm{~mm}$ compr., filetes conatos, apêndices do tubo estaminal ausentes; ovário e pistilódio globosos $1 \mathrm{~mm}$ compr., $1 \mathrm{~mm}$ larg., estigma $1 \mathrm{~mm}$ compr. Fruto globoso, $4 \mathrm{~mm}$ compr., $3 \mathrm{~mm}$ larg., pericarpo do fruto imaturo verde, denso em cavidades secretoras com conteúdo escuro.

Diferencia-se de M. lancifolia pelas folhas menores e mais estreitas, pela ausência de pelos nos ramos e nas terminações e, principalmente, pelo ápice emarginado. Ocorrência verificada somente em campos rupestres do estado de Minas Gerais e campos de altitude do estado do Rio de Janeiro. Material selecionado: MINAS GERAIS: Congonhas do Norte, 20.V.1989, G. Hatschbach 52972 (MBM, RB); Diamantina, estrada Diamantina-Mendanha, 10.XII.1992, H. F. Leitão Filho 27733 et al. (UEC); Ouro Preto, Serra do Itacolomi, X.2000, M. F. Freitas 307 et al. (UEC, RB). RIO DE JANEIRO: Santa Maria Madalena, Pedra do Desengano, 1800msm, 30.VI.1989, G. Martinelli 13400 et al. (RB).

7. Myrsine gardneriana A. DC., Ann. Sci. Nat. Bot. ser. 2, 16: 86.1841. Tipo: Brasil Serra dos Órgãos, 1838, Gardner 528 (holótipo, G; isótipo, BM)

Fig. 2a-d

Árvores e arvoretas (1-)2,5-10(-20) m alt., ramos terminais $1,5 \mathrm{~mm}$ diâmetro, glabros, casca interna avermelhada. Folhas cartáceas a coriáceas, glabras, lisas, ovado-lanceoladas, ápice agudo a acuminado, base aguda, revoluta na face abaxial $(4,5) 6-10(17,5) \mathrm{cm}$ compr., 1,5-3(5) cm larg., margem inteira, levemente revoluta, nervura principal proeminente em ambas as faces, na face inferior com $1 \mathrm{~mm}$ largura na base foliar, linhas translúcidas densas em folhas jovens e quando visíveis em folhas adultas são esparsas e curtas, nervuras secundárias evidentes apenas no material desidratado; pecíolo alvo-esverdeado, geralmente avermelhados, 4-8mm compr. Inflorescências com pedúnculo curto, 1-3(5) mm compr.; 8-11(13) flores, bractéolas $1 \mathrm{~mm}$ compr., triangulares, tricomas curtos. Flores pentâmeras, $4-6 \mathrm{~mm}$ compr.; pedicelos (2)3-4(5) mm compr.; sépalas 1 $\mathrm{mm}$ compr., triangulares, tricomas curtos, esparsos, cavidades secretoras globosas com conteúdo escuro; pétalas 2-3(3,5) mm compr., 0,8-1 mm larg., cavidades secretoras elípticas e lineares em maior densidade que globosas; estames 1-1,5 mm compr., estaminódios $0,7-1 \mathrm{~mm}$ compr.; filetes conatos, apêndices do tubo estaminal ausentes; ovário globoso $1 \mathrm{~mm}$ compr., $1 \mathrm{~mm}$ larg., pistilódio cônico 1-1,2 mm compr.; estigma $1 \mathrm{~mm}$ compr. Fruto globoso, 4-5 mm compr., 3,5-4 mm larg., pericarpo com cavidades secretoras visíveis.

Myrsine gardneriana é uma espécie bem representada nas regiões sudeste e sul do Brasil e muito confundida com M. umbellata, que apresenta folhas maiores, flores com pedicelos maiores e em maior número e pecíolos alvos. Os indivíduos apresentam comumente o pecíolo e a casca interna avermelhados, e nos campos de altitude toda a inflorescência é rosada. Ocorrem comumente em formações florestais de todos os estados, especialmente em regiões de maiores altitudes e à margem de áreas úmidas.

Material selecionado: ESPÍRITO SANTO: Castelo, Forno Grande, 1600msm, 18.V.1949, A.C. Brade 19867 (RB); MINAS GERAIS: São Roque de Minas, Serra da Canastra, 17.IV.1994, J.N. Nakajima 269, 385 et al. (HUFU); PARANÁ: Rolândia, Faz. Conquista, 14.XII.1999, M.F. Freitas et al. 293 (FUEL, UEC); RIO DE JANEIRO: Itatiaia, estr. próxima a entrada da Reserva, 5.X.1991, S.A. Nicolau et al. 233 (SP, RB); RIO GRANDE DO SUL: São Francisco de Paula, 18.II.1993, R. Wasum et al. (HUCS 8951); SANTA CATARINA: São José, Serra da Boa Vista, 2.II.1953, Reitz 5447 (HRB, PACA); SÃO PAULO: Lavrinhas, IV.1995, L.S. Kinoshita et al. 9514 (UEC);

8. Myrsine glazioviana Warm., Kjoeb. Vidensk. Medell. 17.1874. Tipo: Minas Gerais, Serra de Capanema, Glaziou 15190 (Lectótipo: C); Entre Serrinha e Ibitipoca, Schwacke 12531 (RB); Serra dos Órgãos, Rio de Janeiro, Glaziou 3440, 6067, 17122 (C), 3640 (R); Sem localidade: Sellow 887, 904, 908 (B)

Fig. 2e-h.

Arbustos 3-4 m alt., ramos terminais ca.1,5 mm diâmetro, tricomas não ramificados, ferrugíneos. Folhas cartáceas, membranáceas, pilosas nas nervuras, lisas, ovadas, ápice agudo a arredondado, base ovada, revoluta na face abaxial, $3-5 \mathrm{~cm}$ compr., 2-3 cm larg., margem inteira, nervura principal proeminente na face abaxial e com $1 \mathrm{~mm}$ largura na base foliar, cavidades secretoras globosas em folhas jovens e adultas, nervuras secundárias evidentes apenas no material desidratado; pecíolo alvo-esverdeado, 2-3 mm compr. Inflorescências com pedúnculo curto, 1-2 


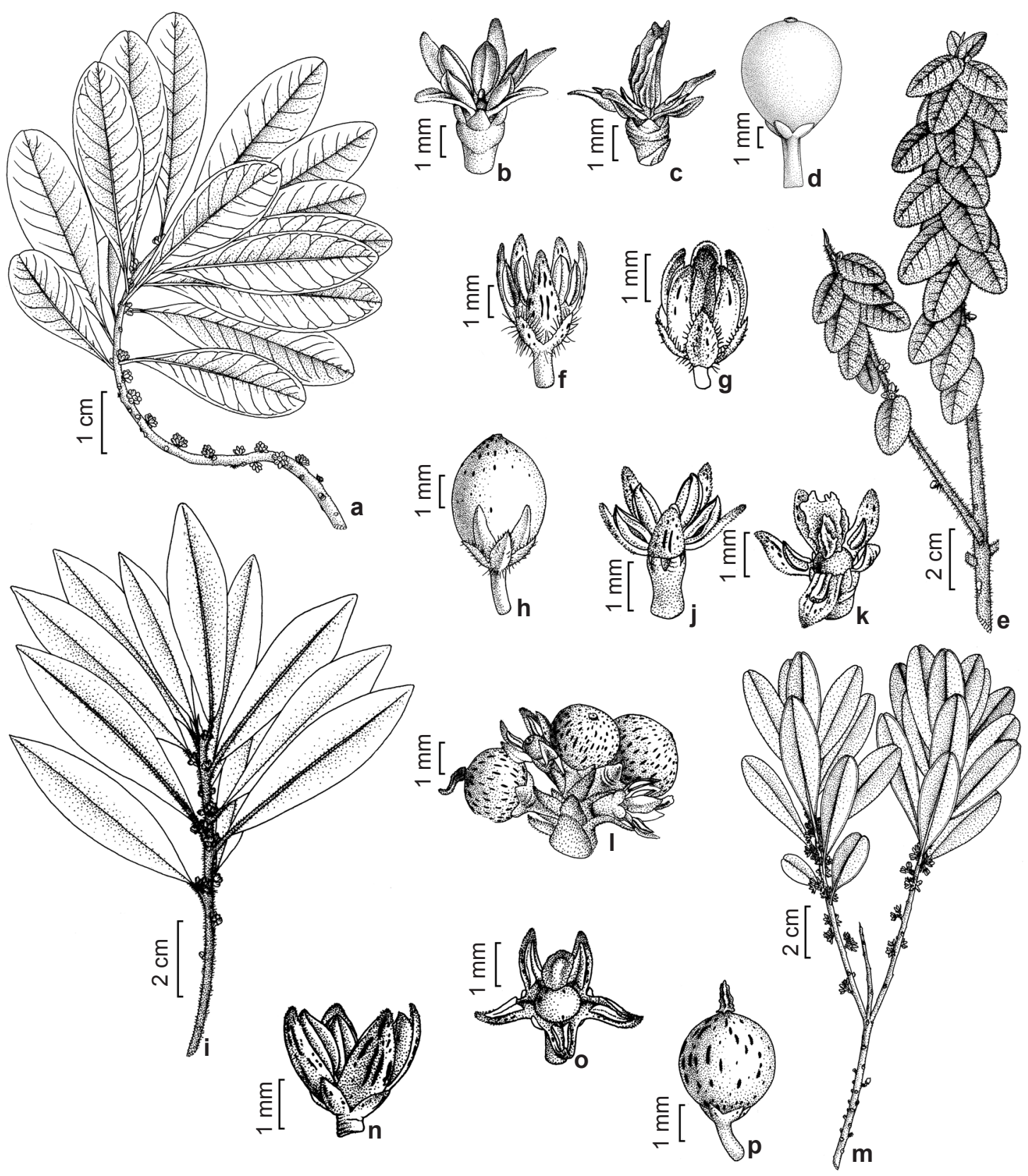

Figura 1 - a-d. Myrsine balansae. a. ramo com frutos. b. flor estaminada. c. flor pistilada. d. fruto (a. Pizzaia 60. b.c. Mendaçolli 1074, 1075, d. Paiva s.n., FUEL 24545). e-h. M. congesta. e. ramo com frutos, f. flor estaminada. g. flor pistilada. h. fruto (e,h. Krieger s.n. CESJ 8643, f. Giullieti CFSC 5629, g. Schwacke 3184 ). i-1. M. coriacea. i. ramo com flores, j. flor estaminada, k. flor pistilada com fruto em formação, 1. frutos e bractéolas. (i, j. Freitas 868 , k,1. Freitas 300). m-p. M. emarginella. m. ramo com flores, n. flor estaminada, o. flor pistilada, p. fruto. (m, o, p. Leitão-Filho 27733, n. Hatschbabh 52972).

Figure 1 - a-d. Myrsine balansae. a. branch with fruits. b. staminate flower. c. pistillate flower. d. fruit (a. Pizzaia 60. b.c. Mendaçolli 1074, 1075, d. Paiva s.n., FUEL 24545). e-h. M. congesta. e. branch with fruits, f. staminate flower. g. pistillate flower. h. fruit (e,h. Krieger s.n. CESJ 8643, f. Giullieti CFSC 5629, g. Schwacke 3184 ). i-1. M. coriacea. i. branch with flowers, j. staminate flower, k. pistillate flower with developing fruit, 1. fruits and bracteoles. (i, j. Freitas 868, k,1. Freitas 300). m-p. M. emarginella. m. branch with flowers, n. staminate flower, o. pistillate flower, p. fruit. (m, o, p. Leitão-Filho 27733, n. Hatschbabh 52972). 
mm compr.; 12-17 flores, bractéolas 1-1,3 mm compr., triangulares, tricomas na margem e em ambas as faces das bractéolas. Flores pentâmeras, 3-4 mm compr.; pedicelos 0,5-1 mm compr.; sépalas $1 \mathrm{~mm}$ compr., ovadas, tricomas curtos, densos, cavidades secretoras globosas e elípticas com conteúdo escuro; pétalas $1 \mathrm{~mm}$ compr., 0,8 mm larg., cavidades secretoras globosas e elípticas, poucas, porém em maior densidade que as lineares; geralmente uma alongada no centro da pétala; estames e estaminódios com $1 \mathrm{~mm}$ compr., filetes conatos, apêndices do tubo estaminal ausentes; ovário globoso e pistilódio $1 \mathrm{~mm}$ compr, $1 \mathrm{~mm}$ larg; estigma 1-2 mm compr. Fruto globoso, 3 $\mathrm{mm}$ compr., $3 \mathrm{~mm}$ larg., pericarpo do fruto imaturo verde denso cavidades secretoras com conteúdo escuro.

Espécie pilosa como $M$. congesta, mas com folhas ovadas, amplas, com potencial ornamental. Ocorre em campos rupestres no estado de Minas Gerais, muito comum no Parque Estadual de Ibitipoca, e conhecida pelo exemplar tipo na Pedra do Sino, Rio de Janeiro, sendo recoletada somente em 1929.

Material selecionado: MINAS GERAIS: Lima Duarte, Serra de Ibitipoca, III.1999, M.A. Manhães 1 (CESJ); 3.XI.1973, P.L. Krieger (CESJ 13228). RIO DE JANEIRO: Teresópolis, Serra dos Órgãos, 22.X.1872, Glaziou 3640 (R); 19.IX.1887, Glaziou 17122 (C, P)

9. Myrsine guianensis (Aubl.) O. Kuntze, Rev. gen. 2.402.1891. Rapanea guianensis Aubl., Hist. P1. Gui. Française 1.121.1775. Tipo: Guiana Francesa, tab. 46.1775 (estampa de Aublet?). $\quad$ Fig. 2i-1

Árvores e arvoretas 4-10(20) m alt. ou arbustos $1-1,5 \mathrm{~m}$ alt., ramos terminais 5-7 $\mathrm{mm}$ diâmetro, glabros. Folhas cartáceas a coriáceas, glabras, lisas, ovadas, elípticas, ápice obtuso a arredondado, base aguda, revoluta na face abaxial, 10-13,5 cm compr., 4,5-5,5 cm larg., margem inteira, levemente revoluta, nervura principal proeminente em ambas as faces, na face inferior com 1,5-2 $\mathrm{mm}$ largura na base foliar, linhas translúcidas visíveis raras, nervuras secundárias não impressas na face abaxial nem evidentes no material desidratado; pecíolo alvoesverdeado, 8-15(20) mm compr. Inflorescências com pedúnculo curto, 2-4 mm compr.; bractéolas 1-1,5 mm compr., triangulares, tricomas curtos. Flores pentâmeras, 4-6 mm compr.; pedicelos 2-3 mm compr.; sépalas $1 \mathrm{~mm}$ compr., triangulares, tricomas curtos, esparsos, cavidades secretoras globosas com conteúdo escuro; pétalas 2,5-3 mm compr., $1 \mathrm{~mm}$ larg., cavidades secretoras elípticas e lineares em maior densidade que as globosas; estames e estaminódios ca. 1,5 mm compr., filetes conatos. apêndices do tubo estaminal ausentes; ovário globoso $5 \mathrm{~mm}$ compr e $1 \mathrm{~mm}$ de larg., pistilódio cônico ca. 1,2 mm compr.; estigma 1 $\mathrm{mm}$ compr. Fruto globoso, 5-6 mm compr., 5,5-6 $\mathrm{mm}$ larg., pericarpo do fruto imaturo verde, poucas cavidades secretoras com conteúdo escuro.

Myrsine guianensis é uma espécie de hábito arbóreo, podendo ser arbustivo em vegetação de restinga, de folhas amplas. Os indivíduos de $M$. guianensis que ocorrem no estado do Rio Grande do Sul são muito confundidos $\operatorname{com} M$. umbellata e M. balansae. Diferenciam-se destas por apresentar ramos muito robustos e pedicelo reduzidos. Ocorre no Brasil, da região Amazônica ao Rio Grande do Sul, não havendo registros para a região central. Indivíduos de menor porte ocorrem em áreas de restinga. Otegui (1998) cita a ocorrência desta espécie no Paraguai.

Material selecionado: ESPÍRITO SANTO: Mun. Conceição da Barra, Itaúnas, 21.IX.1993, O.J. Pereira et al. 4887 (VIES); MINAS GERAIS: Mun. Belo Horizonte, II.1964, A. Sampaio 6626 (R); PARANÁ: Paranaguá, Ilha do Mel, Morro Bento Alves, 26.III.1988, S.M. Silva et al. 1473 (FUEL, RB); RIO DE JANEIRO: Mun. Macaé, 8.VII.1994, C. Farney et al. 3405 (GUA, RB); RIO GRANDE DO SUL: Porto Alegre, Morro Santana, 18.VI.1987, N. Silveira 4738 (HAS); SANTA CATARINA: Florianópolis, 13.VI.1987, D.B. Falkenberg 4386 (FLOR); SÃO PAULO: Cananéia, Ilha do Cardoso, Morro do Marujá, VII.1989, F. de Barros et al. 1683 (SP, IAC); São Vicente, 16.VIII.1947, A.B. Joly et al. (SPF 62842).

10. Myrsine hermogenesii (Jung-Mendaçolli \& Bernacci) M.F.Freitas \& Kin.-Gouv. Bradea 10(1): 2.2004. Rapanea hermogenesii Jung-Mendaçolli \& Bernacci, Bol. Bot. Univ. São Paulo 16:31-35.1997. Tipo: Brasil, São Paulo, São Paulo, nativa no Jardim Botânico, 22.VIII.1948, fl., O. Handro 2 (holótipo, IAC; isótipo, SP)

Árvores e arvoretas 6-10 m alt., ramos terminais 3-4 mm diâmetro, glabros. Folhas membranáceas a cartáceas, glabras, lisas, ovadolanceoladas a espatuladas, ápice agudo-acuminado, base aguda, revoluta na face abaxial, 14-19 cm compr., 3-5 cm larg., margem inteira, levemente revoluta, nervura principal proeminente em ambas as faces, na face inferior com $1 \mathrm{~mm}$ largura na base foliar, linhas translúcidas evidentes na nervura 
principal da face abaxial de folhas jovens e adultas, no limbo são visíveis apenas em folhas jovens; nervuras secundárias não impressas na face abaxial, pouco evidentes no material desidratado; pecíolo alvo-esverdeado a avermelhado, 7-10 mm compr. Inflorescências umbeliformes, pedúnculo $1 \mathrm{~mm}$ compr.; bractéolas 1-1,5 mm compr., triangulares, tricomas curtos. Flores pentâmeras, 5-6 mm compr.; pedicelos 1,5-2 mm compr.; sépalas $1 \mathrm{~mm}$ compr., triangulares, tricomas curtos, esparsos, quase glabras, cavidades secretoras globosas; pétalas 3,5-4 mm compr., $1 \mathrm{~mm}$ larg., cavidades secretoras globosas e elípticas; estames 1,5-2 mm compr., estaminódios 1,5 mm compr., filetes conatos, apêndices do tubo estaminal ausentes; ovário elíptico-globoso 1,8-2 mm compr e $1 \mathrm{~mm}$ de larg, pistilódio cônico 1,2 mm compr.; estigma 2-2,5 mm. Fruto elipsóide, (7)8-9 mm compr., 5-8 $\mathrm{mm}$ larg., pericarpo do fruto imaturo verde com cavidades secretoras pouco visíveis.

Apresenta os maiores frutos dentre as espécies aqui tratadas. As linhas translúcidas na nervura principal e as folhas ovado-lanceoladas, com ápice agudo-acuminado são as características mais importantes que a distingue de $M$. umbellata em estágio vegetativo. Ocorrem em floresta atlântica nos estados de Minas Gerais, Paraná, Rio de Janeiro, Rio Grande do Sul, Santa Catarina e São Paulo. Ilustração em Freitas \& Kinoshita (2004). Material selecionado: MINAS GERAIS: Caratinga, Est. Biológica de Caratinga, Faz. Montes Claros, s.d., L.V. Costa 533 (BHCB). PARANÁ: Guaraqueçaba, Morro do Quitumbê ou do Costão, 14.XI.1994, S. Athayde et al. 202 (UPCB). RIO DE JANEIRO: Vista Chineza, 23.VIII.1931, Brade 11009 (RB). RIO GRANDE DO SUL: Torres, Perdida, 29.X.1992, J.A. Karenkow \& $R$ Záchia 2166 (FLOR, PEL); SANTA CATARINA: Blumenau, Bom Retiro, mata da Cia. Hering, 250msm, 15.XII.1959, Klein 2346 (HBR); SÃO PAULO: Pindamonhangaba, III.1994, I. Cordeiro et al. 1348 (ESA, HRCB, IAC, SP).

11. Myrsine laetevirens (Mez) Arechav. Ann. Mus. Nac. Montevideo 7: 38.1909. Rapanea laetevirens Mez in Engl. Pflanz. 3.395. 1902. Tipo: Paraguai, São Bernardino, Hassler 3792 (lectótipo, A)

Fig. $2 m-p$

Árvores e arvoretas 4-8(12) m alt., ramos terminais 3-4 mm diâmetro, glabros, não suberosos. Folhas cartáceas, glabras, lisas, espatuladas, ápice arredondado, base aguda, revoluta na face abaxial, 7-10 cm compr., 2-3 cm larg., margem inteira, levemente revoluta, nervura mediana proeminente em ambas as faces, na face inferior com $1 \mathrm{~mm}$ largura na base foliar, linhas translúcidas raras ou não visíveis, nervuras secundárias não impressas na face abaxial; pecíolo alvo-esverdeado, 5-7 mm compr. Inflorescências umbeliformes a racemosas, eixo com 5-10(30) mm compr.; bractéolas ao longo do eixo, 1,5 mm compr., triangulares, tricomas curtos. Flores pentâmeras, 4-5 mm compr.; pedicelos 1,5-2 mm compr.; sépalas $1 \mathrm{~mm}$ compr., triangulares, tricomas curtos, esparsos, cavidades secretoras globosas com conteúdo escuro; pétalas $3 \mathrm{~mm}$ compr., $1 \mathrm{~mm}$ larg., cavidades secretoras globosas e elípticas em maior densidade que as lineares; estames ca. 1,5 mm compr., estaminódios ca. $1 \mathrm{~mm}$ compr., filetes conatos; apêndices do tubo estaminal ausentes; ovário globoso 1-1,5 mm compr, $1 \mathrm{~mm}$ de larg., pistilódio cônico $1 \mathrm{~mm}$ compr.; estigma 1.mm compr. Fruto globoso, 3 $\mathrm{mm}$ compr., $4 \mathrm{~mm}$ larg, pericarpo do fruto imaturo desidratado, de coloração acinzentada e esverdeado no material vivo, e cavidades secretoras com conteúdo escuro.

Esta espécie foi a mais analisada sob diferentes aspectos morfológicos e químicos (Madrigal et al. 1977; Otegui 1994; Otegui \& Maldonado 1998; Otegui \& Cocucci 1998; Otegui et al. 1998a, 1998b, 1999), sendo geradas informações inéditas para o gênero e para a família. Entre elas a de que apresenta uma característica peculiar que é a inflorescência variando de umbeliforme a pequenos racemos, com eixo que pode alcançar até $3 \mathrm{~cm}$ de compr. No Brasil ocorre nos estados do Paraná ao Rio Grande do Sul e, segundo Otegui (1998), ocorre também na Argentina, Bolívia, Paraguai e Uruguai. Material selecionado: PARANÁ: Sertaneja, Rio Congonhas, 2.IV.1998, E.M. Francisco et al. (FUEL 22061): RIO GRANDE DO SUL: Pelotas, Horto Botânico, 25.I.1956, Sacco 463 (FUEL, HB, HBR, MBM, PEL). SANTA CATARINA: Araranguá Meleiro, 15.X.1943, Pe. R. Reitz c.34 (RB)

12. Myrsine lancifolia Mart. ex A.DC. in DC. Prodr. 8: 100.1844. Tipo: Brasil, Martius 1193, Herb. Fl. Bras. (holótipo, M)

Fig. 3a-d

Arvoretas ou arbustos 2-4 m alt., ramos terminais ca. 2,5 mm diâmetro, tricomas curtos e esparsos no ápice dos ramos terminais, caducos. Folhas cartáceas, glabras, lisas, lanceoladas, ápice agudo a acuminado, base aguda, não revoluta, 9-12 cm compr., 2-2,5 cm larg., margem inteira, levemente revoluta, nervura mediana proeminente em ambas as faces, na face inferior com $1 \mathrm{~mm}$ 


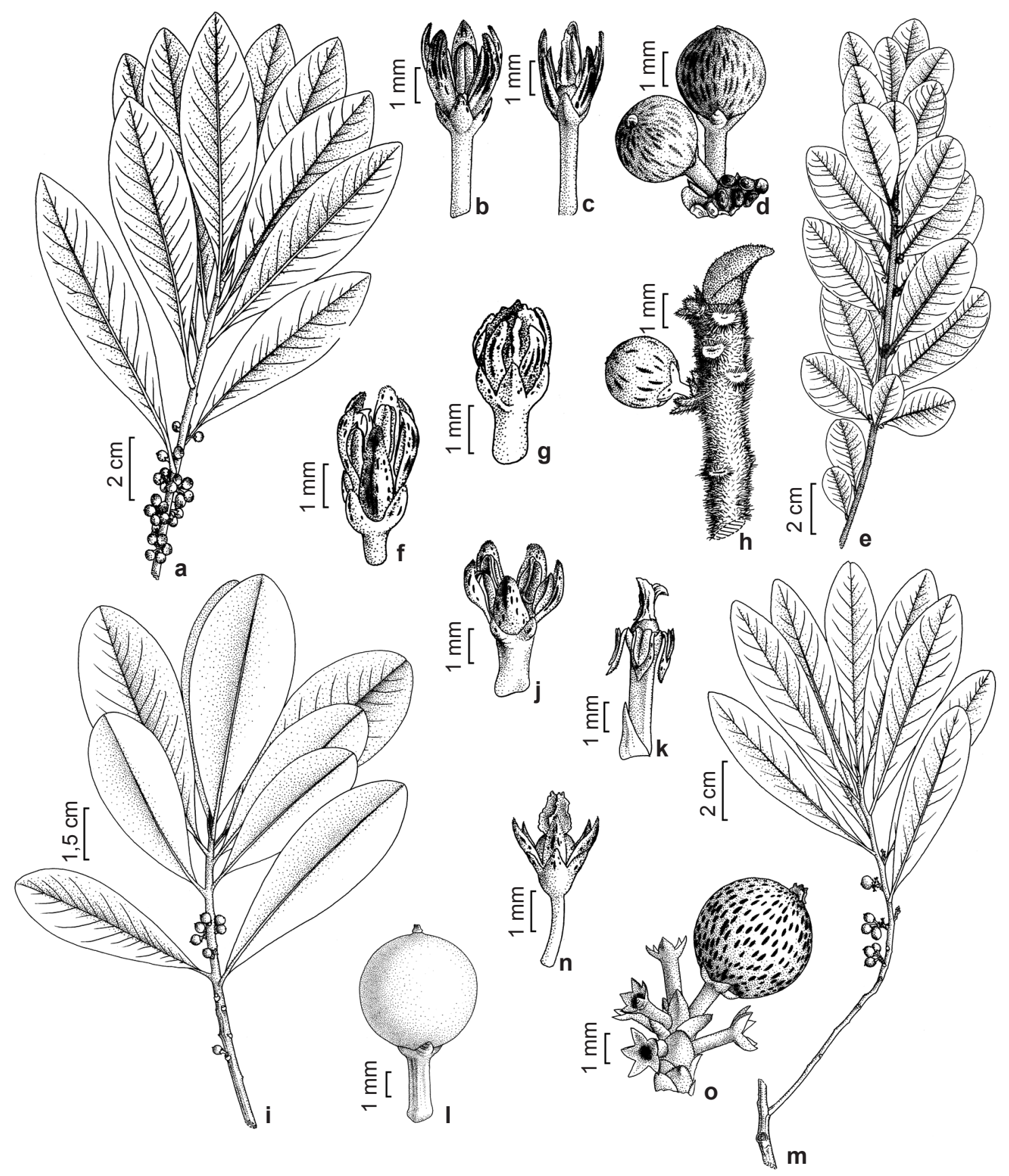

Figura 2 - a-d. Myrsine gardneriana. a. ramo com frutos, b. flor estaminada, c. flor pistilada, d. frutos. (a, d. Nicolau 233, b. Freitas 293, c. Krieger 8489). e-h. M. glazioviana. e. ramo com botões, f. flor estaminada, g. flor pistilada, h. ramo com fruto. (e. Glaziou 17122, f. Glaziou 3640, g. Manhães 1, h. Krieger s.n. CESJ 13228). i-1 M. guianensis. i. ramo com frutos, j. flor estaminada, k. flor pistilada com bractéola, 1. fruto (i, 1. Silva 1473, j. Barros 1683, k. Joly s.n SPF 62842). m-p. M. laetevirens. m. ramo com frutos, $\mathrm{n}$. flor pistilada com fruto em formação, o. ramo com fruto. (m, o. Francisco s.n. FUEL 22061, n. Sacco 463).

Figure 2 - a-d. Myrsine gardneriana. a. branch with fruits, b. staminate flower, c. pistillate flower, d. fruits. (a, d. Nicolau 233, b. Freitas 293, c. Krieger 8489). e-h. M. glazioviana. e. branch with buds, f. staminate flower, g. pistillate flower, h. branch with fruit. (e. Glaziou 17122, f. Glaziou 3640, g. Manhães 1, h. Krieger s.n. CESJ 13228). i-1 M. guianensis. i. branch with fruits, j. staminate flower, k. pistillate flower with bracteole, 1. fruit (i, 1. Silva 1473, j. Barros 1683, k. Joly s.n. SPF 62842). m-p. M. laetevirens. m. branch with fruits, n. pistillate flower with developing fruit, o. branch with fruit. (m, o. Francisco s.n. FUEL 22061, n. Sacco 463). 
largura na base foliar, linhas translúcidas não visíveis em folhas jovens e adultas, nervuras secundárias não impressas na face abaxial, evidentes apenas no material desidratado; pecíolo alvo-rosado, 0,7-1 cm compr. Inflorescências com pedúnculo curto, $1 \mathrm{~mm}$ compr.; bractéolas 1 mm compr., triangulares, tricomas curtos; flores pentâmeras, 3,5-4 mm compr.; pedicelos 1,5-2 mm compr.; sépalas $1 \mathrm{~mm}$ compr., lanceoladas, tricomas curtos, esparsos, cavidades secretoras globosas e elípticas com conteúdo escuro; pétalas $2 \mathrm{~mm}$ compr., $1 \mathrm{~mm}$ larg., cavidades secretoras globosas e elípticas em maior densidade que as lineares; estames 1,5mm compr., tecas assimétricas, estaminódios $1 \mathrm{~mm}$ compr., filetes conatos, apêndices do tubo estaminal ausentes; ovário globoso $1 \mathrm{~mm}$ compr, $1 \mathrm{~mm}$ larg.; estigma 1,5 mm compr. Fruto globoso, 4 mm compr., 3 mm larg., pericarpo do fruto imaturo verde, muitas cavidades secretoras com conteúo do hialino, fruto maduro róseo a violáceo.

Myrsine lancifolia apresenta folhas estreitamente longo-lanceoladas que, somadas às características do fruto, a distingue especialmente de M. gardneriana. Ocorre nos estados de Minas Gerais, Rio de Janeiro, Espírito Santo, São Paulo, Paraná e Santa Catarina.

Material selecionado: ESPÍRITO SANTO: Santa Teresa, Est. Bio. Santa Lúcia, 4.V.1993, L.D. Thomaz 1595 (MBML); MINAS GERAIS: Bonsucesso, 8.I.1950, P.L. Krieger (CESJ 18651); Itabirito, 19.XII.1970, P.L. Krieger (CESJ 9652, MBM 263719); Ouro Preto, Serra de Itacolomi, X.2000, M.F. Freitas et al. 308 (UEC, RB). PARANÁ: Ponta Grossa, arredores da lagoa Dourada, 29.X.1995, F. Chagas e Silva et al. 1851 (FUEL). RIO DE JANEIRO: Nova Friburgo, Macaé de Cima, 6.IV.1989, C.M. Vieira et al. 26 (RB, SP). SANTA CATARINA: Santa Cecília, 1000m, 20.VII.1978, R.M. Klein et al. 12197 (HRB). SÃO PAULO: Campos do Jordão, 23.IV.1974, Mattos 15791 (SP).

13. Myrsine leuconeura Mart., Fl. Beibl. ser. 2, 24: 18.1841. Tipo: Herb. Fl. Bras. 256, São Paulo, s.d., Martius obs. 1021(holótipo, M) Fig. 3e-h

Arvoretas 6-8 m alt., ramos terminais 3-4 mm diâmetro, glabros, casca interna amarelada. Folhas cartáceas, glabras, lisas, elípticas, ápice agudo, base aguda a obtusa, revoluta, (8,5)9-12(13) cm compr., $(3,5) 4-5(6) \mathrm{cm}$ larg., margem inteira, levemente revoluta, nervura principal proeminente em ambas as faces, na face inferior com 1,5 mm largura na base foliar, linhas translúcidas evidentes em folhas jovens e adultas, nervuras evidentes apenas no material desidratado; pecíolo alvo-esverdeado, $(0,5) 0,7-10 \mathrm{~mm}$ compr. Inflorescências pouco densas, esparsas nos ramos, pedúnculo curto, 1,2 mm compr.; 5-8 flores; bractéolas $1 \mathrm{~mm}$ compr., triangulares, tricomas curtos. Flores pentâmeras, 4,5 mm compr.; pedicelos 1,5-2 mm compr.; sépalas $1 \mathrm{~mm}$ compr., triangulares, tricomas curtos, esparsos, cavidades secretoras globosas com conteúdo escuro; pétalas 2-3 mm compr., 1 mm larg., cavidades secretoras globosas e elípticas em maior densidade que as lineares; estames e estaminódios com 1,5 mm compr., filetes conatos, apêndices do tubo estaminal ausentes; ovário globoso 1,2 mm compr, $1 \mathrm{~mm}$ de larg., pistilóides cônicos 0,5 mm compr., estigma 1,8 mm. Fruto globoso, 3-4 mm compr., $3 \mathrm{~mm}$ larg., pedicelo 3-4 $\mathrm{mm}$, pericarpo do fruto imaturo verde, cavidades secretoras pouco visíveis com conteúdo escuro.

Espécie vegetativamente muito semelhante a M. umbellata, diferenciando-se desta pelas folhas menores e elípticas, pedicelos menores e inflorescências pouco densas e esparsamente distribuídas nos ramos. Ocorre nas áreas de cerrado, especialmente ao norte do estado de São Paulo e nos estados de Minas Gerais e Distrito Federal. Material selecionado: MINAS GERAIS: Betim, REPAG, área 5, 29.XI.1995, Pedralli et al. s.n (HXBH 11900); Januária, Fabião, 24.X.1997, J.A. Lombardi 2039 (BHCB, RB); Nova Ponte, 26.VI.1996, E. Tameirão Neto 2064 (BHCB, RB); Vale do Rio Araguari, capoeira José Brás, 30.VII.1993, A.L.P. Mota et al. 1718, 1724 (VIC, HUFU); SÃO PAULO: Mococa, 7.XI.1994, L.S. Kinoshita et al. 94-214 (IAC); Votuporanga, 28.XI.1994, L.C. Bernacci et al. 726 (UEC).

14. Myrsine lineata (Mez) Imkhan., Bot. Zhurn. 81(10): 28.1996. Rapanea lineata Mez in Engl. Pflanz. 9(IV.236):385.1902. Tipo: Minas Gerais, Itacolomi, Schwacke 11527 (síntipo, RB); Rio de Janeiro, Itatiaia, Glaziou 8792 (síntipo, C; isosíntipo, LE); Rio de Janeiro, Alto Macaé de Nova Friburgo, Glaziou 17690 (foto F); Brasil, Tymbopiba, L. Riedel 380 (isosíntipo, LE); Brasil, sem localidade, Glaziou 18347 (isosíntipos, K, LE)

Fig. 3i-1

Arvoretas 5-8 $\mathrm{m}$ alt. ramos terminais 2 $\mathrm{mm}$ diâmetro, glabros. Folhas membranáceas a cartáceas, glabras, lisas, elípticas a lanceoladas, ápice agudo a acuminado, base aguda, levemente revoluta na face abaxial ou não, (6)8-15(20) cm compr., 2,5-3,5 cm larg., margem inteira, levemente revoluta, nervura principal proeminente 
na face abaxial, com $1 \mathrm{~mm}$ largura na base foliar, linhas translúcidas alongadas, oblíquas, visíveis em folhas jovens e adultas, nervuras secundárias não impressas na face abaxial, pouco evidentes no material desidratado; pecíolo alvo-esverdeado, (6)8-12 mm compr. Inflorescências com pedúnculo curto, 1-2 mm compr., 6-10 flores; bractéolas 1-1,2 $\mathrm{mm}$ compr., triangulares a lanceoladas, tricomas curtos. Flores pentâmeras raro tetrâmeras, 4-5(6) mm compr.; pedicelos 1,5-2(4) mm compr.; sépalas 0,8-1 mm compr., triangulares, tricomas curtos, esparsos, cavidades secretoras globosas diminutas e esparsas; pétalas 2-2,5 mm compr., $1 \mathrm{~mm}$ larg., cavidades secretoras globosas e elípticas raras e esparsas; estames 1,5-2 mm compr., secreção escura ao longo do conectivo, estaminódios $1 \mathrm{~mm}$ compr., filetes conatos, apêndices do tubo estaminal ausentes; ovário globoso e pistilódio cônico $1 \mathrm{~mm}$ compr.; estigma $1,5 \mathrm{~mm}$. Fruto globoso, $5 \mathrm{~mm}$ compr., $4 \mathrm{~mm}$ larg., pericarpo do fruto imaturo verde, cavidades secretoras visíveis.

Esta espécie é caracterizada pelas estruturas secretoras dispostas em linhas oblíquas na face abaxial da folha, que se confundem com as nervuras secundárias. As folhas são membranáceas, agudas e odoríferas. O acentuado odor está relacionado a óleos essenciais (Gottlieb \& Salatino 1987) presentes nas cavidades secretoras, identificados nesta espécie.

Ocorre com frequência em altitudes, especialmente em ambientes úmidos e pouco iluminados (Siqueira 1993). Ocorre de Minas Gerais até Santa Catarina.

Material selecionado: MINAS GERAIS: Serra do Caparaó, Cachoeira Bonita, 8.III.1991, M. Brugger et al. (CESJ 22921); PARANÁ: Campina Grande do Sul, Rio Taquary, 9.XII.1956, G. Hatschbach 3427 (MBM); RIO DE JANEIRO: Itatiaia, 17.XI.1994, R. Simão-Branchini 586 (SP); SANTA CATARINA: Ibirama, Horto Florestal, 700msm, 15.VI.1956, Klein et al. 2096 (HBR, MBM); SÃO PAULO: Capão Bonito, Faz. Intervales, 9.X.1989, S.M.R. Alvares 23323 (IUEC), 18.XI.1989, S.M. Alvares 23336 (UEC); Pindamonhangaba, Ribeirão Grande, Faz. São Sebastião, 900msm, 30.III.1994, I. Cordeiro et al. 1348 (ESA, HRCB, IAC, SP).

15. Myrsine loefgrenii (Mez) Imkhan., Bot. Zhurn. 81(10): 28.1996. Rapanea loefgrenii Mez in Engl. Pflanz 9 (IV. 236):382.1902. Tipo: Brasil, Minas Gerais, Caldas, 1864, Regnell III 863 (lectótipo, S).

Fig. $3 m-p$

Arvoretas ou arbustos 2-8 $\mathrm{m}$ alt., ramos terminais $1 \mathrm{~mm}$ diâmetro, glabros. Folhas membranáceas, glabras, lisas, ovadas a lanceoladas, ápice e base agudas, base geralmente não revoluta na face abaxial, (4)5,5-7(9) cm compr., 1,5-2(2,5) $\mathrm{cm}$ larg., margem inteira, nervura principal proeminente na face abaxial e com 0,5 mm largura na base foliar, cavidades secretoras globosas em folhas jovens e adultas, nervuras secundárias não impressas em ambas as faces, evidentes apenas no material desidratado; pecíolo alvo-esverdeado, 4-5 mm compr. Inflorescências com pedúnculo curto, esparsas nos ramos, $1 \mathrm{~mm}$ compr.; 6-7(8) flores, bractéolas $0,7 \mathrm{~mm}$ compr., triangulares, tricomas curtos, poucos. Flores tetrâmeras, 3-4(5) mm compr.; pedicelos ca. 1,5 mm compr.; sépalas $1 \mathrm{~mm}$ compr., triangulares, tricomas curtos, esparsos, cavidades secretoras globosas com conteúdo claro; pétalas 1,5-3 mm compr., 0,7 mm larg., cavidades secretoras globosas e elípticas, raro lineares; estames $1 \mathrm{~mm}$ compr., estaminódios 0,8-1mm compr., filetes conatos, apêndices do tubo estaminal presentes; ovário e pistilódio globosos $1 \mathrm{~mm}$ compr., $1 \mathrm{~mm}$ de larg; estigma $2 \mathrm{~mm}$. Fruto globoso, $4 \mathrm{~mm}$ compr., 3,5 mm larg., pericarpo do fruto imaturo verde, cavidades secretoras pouco visíveis.

Myrsine loefgrenii tem as folhas muito estreitas e membranáceas. É conhecida popularmente como "capororoquinha", ocorre em São Paulo e na região sul do Brasil.

Imkhanitskaya (1996) publicou os tipos nomenclaturais de algumas Myrsinaceae neotropicais que estão depositados no Herbário de Leningrado (LE). Neste trabalho designou uma nova combinação para Rapanea loefgrenii Mez. Posteriormente, Otegui (1998), sem conhecer o trabalho deste autor, publicou novamente uma nova combinação para esta espécie.

Material selecionado: PARANÁ: Cambé, Parque Danziger Hoff, 14.XII.1999, M.F. Freitas et al. 295, 296 (FUEL, UEC); 21.VII.2000, E.M. Francisco (FUEL 27629, RB 380471); RIO GRANDE DO SUL: Barra do Ribeiro Guaíba, 14.XI.1948, B. Rambo (PACA 38013, RB 200904). SANTA CATARINA: Concórdia, 4.I.1957, L.B. Smith et al. 9921 (R); SÃO PAULO: Jahu, Faz. St. Antônio, 6.VII.1988. E.M. Nicolini (HRCB 11926);

16. Myrsine monticola Mart, Flora Beibl. ser. 2, 24: 18.1841. Tipo: Herb. Fl. Bras. 258. Minas Gerais, s.d., Martius (holótipo, M)

Fig. 4a-d

Arbustos 1-4 m alt., súber espesso no tronco e ramos; fissurados e tortuosos com casca interna avermelhada; ramos terminais 4-5 mm diâmetro, glabros. Folhas coriáceas, glabras, lisas, ovadas a elípticas, ápice obtuso a arredondado, levemente 


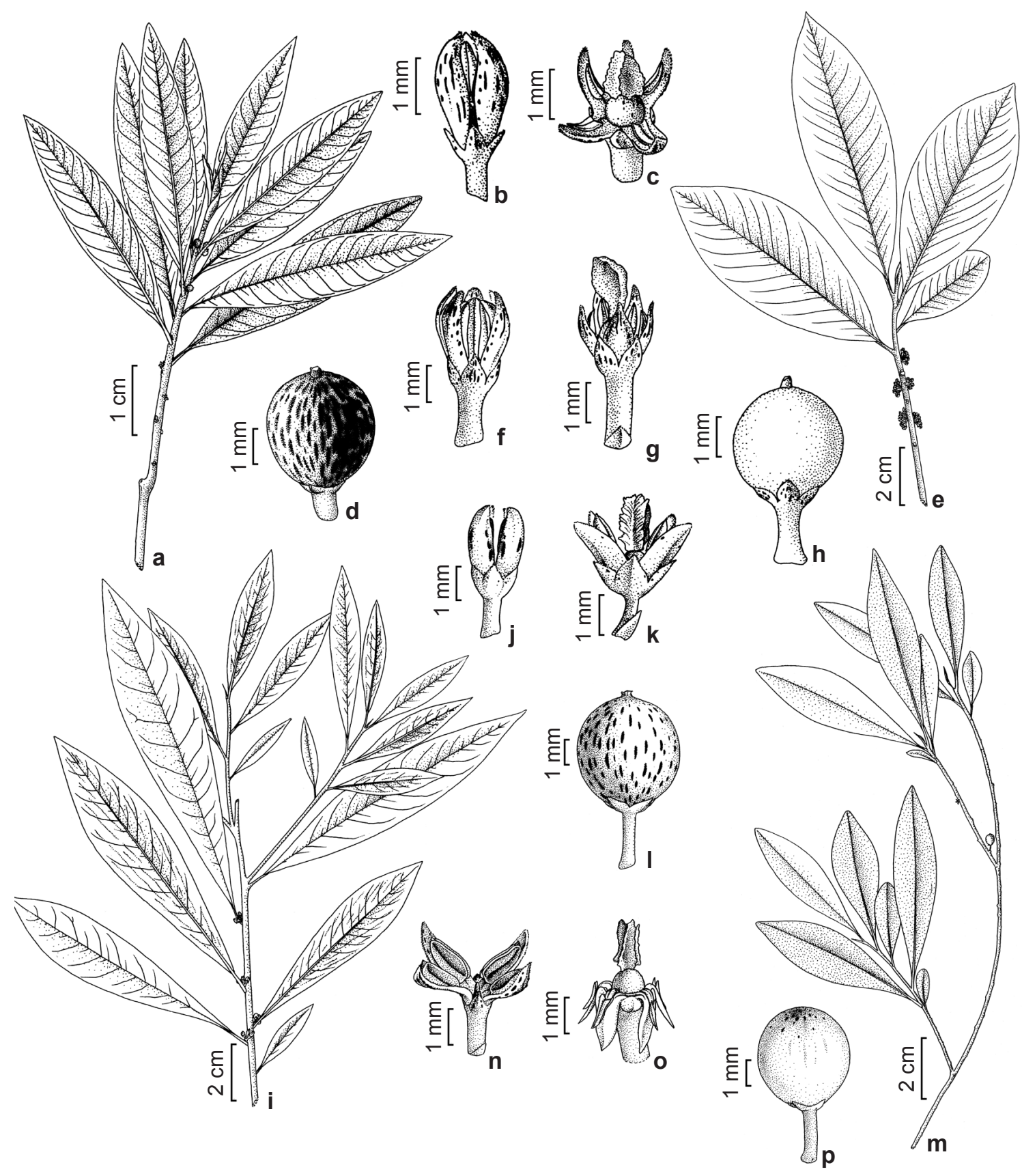

Figura 3 - a-d. Myrsine lancifolia. a. ramo com frutos, b. flor estaminada, c. flor pistilada, d. fruto. (a,d. Freitas 308, b. Krieger s.n. CESJ 18651, c. Krieger s.n. CESJ 9652). e-h. M. leuconeura. e. ramo com flores, f. flor estaminada, g. flor pistilada, h. fruto. (e, g. Tameirão Neto 2064, f. Pedralli s.n. HBXH 11900, h. Lombardi 2039). i-1. M. lineata. i. ramo com flores, j. flor estaminada, k. flor pistilada, 1. fruto. (i, j. Cordeiro 1348, k. Alvares 23336, 1. Alvares 23323). m-p. M. loefgrenii. m. ramo com frutos, n. flor estaminada, o. flor pistilada, p. fruto. (m, p. Freitas 295, n. Nicolini s.n. HRCB 11926, o. Francisco s.n. FUEL 27629)

Figure 3 - a-d. Myrsine lancifolia. a. branch with fruits, b. staminate flower, c. pistillate flower, d. fruit. (a,d. Freitas 308, b. Krieger s.n. CESJ 18651, c. Krieger s.n. CESJ 9652). e-h. M. leuconeura. e. branch with flowers, f. staminate flower, g. pistillate flower, h. fruit. (e, g. Tameirão Neto 2064, f. Pedralli s.n. HBXH 11900, h. Lombardi 2039). i-1. M. lineata. i. branch with flowers, j. staminate flower, k. pistillate flower, 1. fruit. (i, j. Cordeiro 1348, k. Alvares 23336, 1. Alvares 23323). m-p. M. loefgrenii. m. branch with fruits, n. staminate flower, o. pistillate flower, p. fruit. (m, p. Freitas 295, n. Nicolini s.n. HRCB 11926, o. Francisco s.n. FUEL 27629) 
emarginado, base aguda a obtusa, revoluta na face abaxial, (3)5-7(8) cm compr., (1,5)2-3(5) $\mathrm{cm}$ larg., margem inteira, levemente revoluta, nervura mediana proeminente em ambas as faces, na face inferior com 1-1,5(2) mm largura na base foliar, linhas translúcidas não visíveis, nervuras secundárias não impressas na face abaxial, não evidentes no material desidratado; pecíolo alvoesverdeado, 3-5 mm compr. Inflorescências com eixo longo, 3-5 mm compr., 6-8 flores; bractéolas $1 \mathrm{~mm}$ compr., triangulares, tricomas curtos. Flores pentâmeras, 4-5 mm compr.; pedicelos 1-2 mm compr.; sépalas $1 \mathrm{~mm}$ compr., triangulares, tricomas curtos, esparsos, cavidades secretoras com conteúdo escuro; pétalas $2 \mathrm{~mm}$ compr., $1 \mathrm{~mm}$ larg., cavidades secretoras globosas e elípticas em maior densidade que as lineares; estames 1,5-2 mm compr., estaminódios $1 \mathrm{~mm}$ compr.; filetes conatos, apêndices do tubo estaminal presentes, alternos aos lobos da corola; ovário globoso e pistilódio cônico, $1 \mathrm{~mm}$ compr.; estigma 1,5-2 mm. Fruto globoso, 4-5 mm compr., 4-5 mm larg., pericarpo do fruto imaturo verde, denso em cavidades secretoras com conteúdo escuro.

Planta com folhas coriáceas, tronco e ramos suberosos, fissurados e tortuosos, casca interna avermelhada. O eixo da inflorescência é geralmente longo e persistente no ramo, podendo posteriormente dar origem a novo ramo foliar. Ocorre em regiões de campos rupestres e cerrado, principalmente, nos estados da Bahia, Minas Gerais, São Paulo e Brasil central.

Material selecionado: MINAS GERAIS: Carrancas, 16.II.2000, L.S. Kinoshita et al. (UEC 135119); Grão Mogol, entre Cristália e Mumbucas, 22.VII.1985, G. Martinelli et al. 11241 (RB, BHCB); Moeda, Serra da Moeda, 18.X.1987, A. Salino 3605 (BHCB); PARANÁ: Arapoti, Faz. Chapada Sto. Antônio, 5.XII.1990, G. Hatschbach et al. 54878 (MBM). SÃO PAULO: Itirapina, 25.I.1999, M.F. Freitas et al. 255 (UEC).

17. Myrsine parvifolia A. DC., Ann. Sci. Nat. ser. 2. 16: 87.1841. Tipo: Brasil, Ilha de Santa Catarina, 1834, Gaudichaud 297 (holótipo, G) Fig. 4e-h Arbustos (1)1,5-2(3) m alt., ramos terminais $3 \mathrm{~mm}$ diâmetro, glabros. Folhas coriáceas, glabras, lisas, obovadas, ápice, emarginado, base aguda, não revoluta na face abaxial, (2,5)3,5-5 cm compr., 1,5-1,8(2) cm larg., margem inteira, levemente revoluta, nervura mediana proeminente em ambas as faces, na face inferior com $1 \mathrm{~mm}$ largura na base foliar, linhas translúcidas não visíveis, nervuras secundárias não evidentes; pecíolo alvo- esverdeado, 2-3(4) mm compr. Inflorescências com pedúnculo curto, 1-2 mm compr., 5-7 flores; bractéolas $1 \mathrm{~mm}$ compr., triangulares, tricomas curtos. Flores pentâmeras, 5-6,5 mm compr.; pedicelos (1,5)2,5-3 mm compr.; sépalas $1 \mathrm{~mm}$ compr., triangulares, tricomas curtos, esparsos, cavidades secretoras globosas com conteúdo escuro; pétalas 2,5-3 mm compr., $1 \mathrm{~mm}$ larg., cavidades secretoras globosas e elípticas em maior densidade que as lineares; estames $2 \mathrm{~mm}$ compr., estaminódios $1 \mathrm{~mm}$ compr.; filetes conatos, apêndices do tubo estaminal ausentes; ovário globoso e pistilódio cônico, $1 \mathrm{~mm}$ compr e $1 \mathrm{~mm}$ de larg; estigma 1,5 mm. Fruto globoso, (4)5-6 mm compr., 3-5 mm larg., pericarpo do fruto imaturo verde, cavidades secretoras com conteúdo escuro pouco evidentes.

É caracterizada pelas folhas pequenas, obovadas e coriáceas. Folhas menores e mais estreitas e ramos terminais finos, com $3 \mathrm{~mm}$ diâmetro, a diferenciam de $M$. guianensis, que também ocorre em restinga, e de $M$. monticola, que ocorre nos campos rupestres da Bahia. Planta muito comum em ambientes de restinga do Rio Grande do Sul ao Sergipe, e em áreas próximas a manguezais. Material selecionado: ESPÍRITO SANTO: Guarapari, 29.IX.1987, O.J. Pereira 1129 (VIES); PARANÁ: Paranaguá, Ilha das Cobras, 2.XI.1986, W.S. Souza et al. 24994 (UEC); RIO GRANDE DO SUL: São José do Norte, 29.X.1980, A.B. Coura Neto 52 (HRB, FLOR); RIO DE JANEIRO: Angra dos Reis, Ilha Grande, Res. Biol. Praia do Sul, 11.IV.1984, D. Araújo et al. 6182 (GUA); SANTA CATARINA: Araquari, Barra do Sul, 29.X.1953, Reitz 5776 (PACA, HBR, MBM). SÃO PAULO: Cananéia, Ilha do Cardoso, V.2000, M.F. Freitas 301, 302 (UEC);

18. Myrsine parvula (Mez) Otegui, Candollea 53: 152.1998. Rapanea parvula Mez in Eng. Pflanz. 9(IV.236):384.1902. Tipo: Brasil, Rio de Janeiro, Glaziou 7739, 12067 (síntipos, P; isosíntipos, BR, C, R, S)

Fig. 4i-1

Arvoretas 3-5(12) m alt., ramos terminais ca. 1,6 mm diâmetro, glabros. Folhas membranáceas a cartáceas, glabras, lisas, elípticas a lanceoladas, ápice agudo a acuminado, base aguda, levemente revoluta na face abaxial, 5-8(9) cm compr., $(1,5) 2-2,5(3) \mathrm{cm}$ larg., margem inteira, levemente revoluta, nervura mediana proeminente em ambas as faces, na face inferior com 0,7-1 mm largura na base foliar, linhas translúcidas elípticas densas, com conteúdo escuro quando desidratadas, evidentes em folhas jovens e adultas, nervuras secundárias 
não impressas na face abaxial, pouco evidentes no material desidratado; pecíolo alvo-esverdeado, (4)5-7 mm compr. Inflorescências esparsas nos ramos, pedúnculo curto, 1-2 mm compr., 5-8 flores; bractéolas $1 \mathrm{~mm}$ compr., triangulares, tricomas curtos. Flores pentâmeras, 6-7 mm compr.; pedicelos $(2,5) 3-4 \mathrm{~mm}$ compr.; sépalas 1 mm compr., triangulares, tricomas curtos, esparsos, cavidades secretoras globosas ou ausentes; pétalas 2,5-3 mm compr., $1 \mathrm{~mm}$ larg., lanceoladas, cavidades secretoras globosas e lineares; estames $2 \mathrm{~mm}$ compr., estaminódios $1 \mathrm{~mm}$ compr., filetes conatos, apêndices do tubo estaminal ausentes; ovário globoso $1 \mathrm{~mm}$ compr, $1 \mathrm{~mm}$ larg., pistilódio cônico $1 \mathrm{~mm}$ compr.; estigma $1 \mathrm{~mm}$. Fruto globoso, 4-6 mm compr., $3 \mathrm{~mm}$ larg., pericarpo do fruto imaturo verde, poucas cavidades secretoras.

Espécie próxima de $M$. loefgrenii, porém com folhas, pedicelos e frutos maiores. Quando desidratada, a face abaxial da folha torna-se acinzentada, o que permite notar mais claramente as densas cavidades secretoras com conteúdo escurecido. Ocorre no nordeste do Paraguai, no Uruguai e na Argentina (Otegui 1998) e no Brasil do Espírito Santo ao Rio Grande do Sul, com um registro no estado do Mato Grosso do Sul.

Material selecionado: ESPÍRITO SANTO: Domingos Martins, 12.V.1993, J.R. Pirani et al. 2819 (RB). PARANÁ: Londrina, 14-15.XII.1999, M.F. Freitas et al. 299 (FUEL, RB); Mauá da Serra, 22.IX.1998, E.M. Francisco et al. (FUEL 23820). RIO DE JANEIRO: Santa Maria Madalena, Pedra Dubois, $110 \mathrm{msm}$, 8.III.1935, S. Lima \& Brade 14232 (RB). RIO GRANDE DO SUL: Novo Hamburgo, Pq. Municipal, 28.IX.1992, R. Wasum et al. (HUCS 8685). SANTA CATARINA: Jaraguá do Sul, Serra do Boi, 15.X.1989, C.B. Jaster et al. 140 (MBM). SÃO PAULO: Barra do Turvo, BR 116, 8.II.1995, L. Sakai et al. 32666 (SPF, UEC).

19. Myrsine rubra M.F.Freitas \& Kin.-Gouv. Rodriguésia 56 (87): 70.2005. Tipo: Brasil. Paraná: Paranaguá, Ilha Rasa da Cotia, 3.IV.1987, fr., Y. S. Kuniyoshi \& Fr. Galvão 5563 (holótipo, MBM).

Árvores e arvoretas 4-10 m alt., casca interna vermelha escura, ramos terminais $2 \mathrm{~mm}$ diâmetro, glabros. Folhas cartáceas, glabras, lisas, ovadas, elípticas, ápice agudo a acuminado, base aguda, revoluta na face abaxial, $8-10 \mathrm{~cm}$ compr., $2-3 \mathrm{~cm}$ larg., margem inteira, levemente revoluta, nervura principal proeminente em ambas as faces, na face inferior com 1,5 mm largura na base foliar, linhas translúcidas raras e evidentes somente em folhas jovens, nervuras secundárias não evidentes; pecíolo
0,5-0,8 mm compr. Inflorescências com pedúnculo curto, 1-2 mm compr., 6-12 flores; bractéolas 0,5 mm compr., triangulares, tricomas curtos. Flores pentâmeras, 3-4 mm compr.; pedicelos 0,5-1 mm compr.; sépalas $0,8-1 \mathrm{~mm}$ compr., ovadas, tricomas curtos, esparsos, cavidades secretoras globosas; pétalas $2 \mathrm{~mm}$ compr., $1 \mathrm{~mm}$ larg., cavidades secretoras globosas esparsas; estames e estaminódios com $1 \mathrm{~mm}$ compr., filetes conatos; apêndices do tubo estaminal ausentes; ovários elipsóides e pistilódios cônicos, com $1 \mathrm{~mm}$ compr. e $1 \mathrm{~mm}$ larg; estigma 1,5 mm. Fruto elipsóide, 6-7 mm compr., 2,5-3 mm larg.

Myrsine rubra diferencia-se de $M$. umbellata pelas folhas menores e mais estreitas. Os pecíolos e pedicelos são menores, e os frutos elipsóides. A casca interna tem cor vermelha, que se mantém mesmo após a herborização. Ocorre do estado do Espírito Santo ao sul do Paraná próximo a ambientes alagados de vegetação de restinga. Ilustração em Freitas \& Kinoshita (2005).

Material selecionado: ESPÍRITO SANTO: Linhares, estrada da Bomba d'Água, no final da estrada, 15.VI.1989, D.A. Folli 929 (CVRD, RB); RIO DE JANEIRO: Macaé, entre lagoa Comprida e Carapebus, 18.IX.1986, D. Araújo et al. 7591 (GUA, RB); PARANÁ: Paranaguá, Vila Balneária, 24.VII.1947, G. Hatschbach 757 (MBM, RB).

20. Myrsine squarrosa (Mez) M.F.Freitas \& Kin.Gouv. Bradea 10(1): 3.2004. Rapanea squarrosa Mez in Engl. Pflanzenreich 9(IV.236):390.1902. Tipo: Brasil, Minas Gerais, Caldas, 1845, Regnell I 53a, I53. (síntipos, S)

Arbustos 1-2 $\mathrm{m}$ alt., ramos terminais 2-4 mm diâmetro, glabros. Folhas coriáceas, congestas no ápice dos ramos, glabras, lisas, elípticas a lineares, ápice agudo, base aguda a obtusa, revoluta na face abaxial, 2,5-3(5) cm compr., 1-1,2 cm larg., margem inteira, levemente revoluta, nervura principal proeminente em ambas as faces, na face inferior com $0,8 \mathrm{~mm}$ largura na base foliar, linhas translúcidas não evidentes em folhas jovens e adultas, nervuras secundárias não impressas na face abaxial, pouco evidentes no material desidratado; pecíolo alvo-esverdeado, 2-4 mm compr. Inflorescências sésseis, 6-7 flores; bractéolas 0,5-0,7 mm compr., triangulares, tricomas curtos. Flores pentâmeras, 2-2,5(3) mm compr.; pedicelos 0,6-1 mm compr.; sépalas $1 \mathrm{~mm}$ compr., triangulares, tricomas curtos, esparsos, cavidades secretoras globosas e elípticas; pétalas 1,5-2 mm compr., $1 \mathrm{~mm}$ larg., cavidades secretoras 
globosas e elípticas; estames e estaminódios com $1 \mathrm{~mm}$ compr., filetes conatos, apêndices do tubo estaminal ausentes; ovário globoso e pistilódio cônico $1 \mathrm{~mm}$ compr e $1 \mathrm{~mm}$ de larg; estigma 1-1,2 mm. Fruto globoso, $4 \mathrm{~mm}$ compr., $3 \mathrm{~mm}$ larg., pericarpo do fruto imaturo verde, denso em cavidades secretoras com conteúdo escuro.

Myrsine squarrosa foi sinonimizada por Otegui (1998) em M. coriacea, porém a primeira é uma espécie glabra, com folhas coriáceas, arbustiva, enquanto $M$. coriacea apresenta folhas cartáceas, tricomas ferrugíneos nos ramos terminais e porte arbustivo a arbóreo. Esta espécie ocorre em campos rupestres do estado de Minas Gerais e nos campos de altitude dos estados do Rio de Janeiro, São Paulo e Santa Catarina. Ilustração em Freitas \& Kinoshita (2004).

Material selecionado: MINAS GERAIS: Brumadinho, Retiro das Pedras, 1480msm., 28.X.1997, A. Barros et al. 157, 185 (BHCB, SP). RIO DE JANEIRO: Nova Iguaçú, Tinguá, REBIO, Pico do Tinguá, estrada da trilha do Rala, Sapé, 1600 m.s.m, 30.I.2002, H.C. de Lima et al. 5994 (RB). SÃO PAULO: Itararé, Campos de São Pedro, 10.XII.1966, J. Mattos 15277 (SP). SANTA CATARINA: Ilhota, Morro do Baú, 17.VII.1966, D. Hunt 6355 (SP).

21. Myrsine umbellata Mart. Flora Beibl. ser. 2, 24:18.1841. Tipo: Herb. Fl. Brasil. 876. s.d., Martius (holótipo, M; isótipos, $\mathrm{BR}, \mathrm{WU}$ )

Fig. $4 m-p$

Árvores e arvoretas (3)6-8(16) m alt., ramos terminais 3-4 mm diâmetro, glabros. Folhas cartáceas, glabras, lisas, ovadas, ápice agudo, base aguda a obtusa, revoluta na face abaxial, 5-15(30) cm compr., 2-5(8) cm larg.,cm compr., margem inteira, levemente revoluta, nervura mediana proeminente em ambas as faces, na face inferior com $1 \mathrm{~mm}$ largura na base foliar, glândulas e linhas translúcidas evidentes em folhas jovens e adultas, nervuras secundárias não impressas na face abaxial, evidentes apenas no material desidratado; pecíolo alvo-esverdeado, $(0,5) 0,8-1,5(2) \mathrm{cm}$ compr. Inflorescências com pedúnculo curto, 1-2(4) $\mathrm{mm}$ compr. 10-15 flores; bractéolas $1 \mathrm{~mm}$ compr., triangulares, tricomas curtos. Flores pentâmeras ou hexâmeras, 5-7 mm compr.; pedicelos 3-5 mm compr.; sépalas $1 \mathrm{~mm}$ compr., agudas, tricomas curtos, esparsos, cavidades secretoras raras, globosas e elípticas; pétalas 3-4 mm compr., 1 $\mathrm{mm}$ larg., agudas, cavidades secretoras lineares em maior densidade que globosas e elípticas; estames 2-2,2 mm compr., estaminódios $0,8-1,2 \mathrm{~mm}$ compr.; filetes conatos, apêndices do tubo estaminal ausentes; ovário globoso 1-1,2 mm compr, $1 \mathrm{~mm}$ larg., pistilódio globoso $1 \mathrm{~mm}$ compr.; estigma 1,5-2 mm. Fruto globoso, 4-5 mm compr., 3-4 $\mathrm{mm}$ larg., pericarpo do fruto imaturo verde, raro cavidades secretoras com conteúdo claro ou não visíveis.

Myrsine umbellata é uma das espécies de distribuição mais ampla, com ocorrência em diversos habitats e muito bem representada nos herbários brasileiros. É caracterizada por flores com longos pedicelos, densamente dispostas nos ramos terminais. Ocorre amplamente na região de estudo.

Material selecionado: ESPÍRITO SANTO: Santa Teresa, Aparecidinha, 16.VI.1999, L. Kollmann 2599 (RB). MINAS GERAIS: Diamantina, 6.VI.1985, $F$. Barros 1131 (SP, RB). PARANÁ: Bocaiúva do Sul, Sesmaria, 29.I.1969, G. Hatschbach 20924 (MBM). RIO DE JANEIRO: Itatiaia, P.N. Itatiaia, 12.IV.1977, G. Martinelli et al. 1617 (RB). RIO GRANDE DO SUL: Camaquã, Pessegueiro, 12.X.1983, M. Sobral 2416 (FLOR). SANTA CATARINA: Blumenau, Faz. Faxinal, 13.XI.1986, D.B. Falkenberg 3834 (FLOR). SÃO PAULO: Águas de Prata, 11.I.1994, V. C. Souza et al. 5013 (IAC).

22. Myrsine venosa A. DC. Ann. Sc. Nat. Ser. 2. 5(16): 86.1841. Tipo: Brasil, Rio de Janeiro, restinga da Tijuca, 1834, M. Lund 219. (holótipo, C)

Fig. 5a-d

Árvore e arvoretas 5-8(15)m alt., ou arbustos $1,5-3 \mathrm{~m}$ alt., ramos terminais $3 \mathrm{~mm}$ diâmetro, glabros, não suberosos. Folhas coriáceas, aromáticas, glabras, lisas, ovadas, elípticas ou obovadas, ápice agudo a acuminado, base aguda, revoluta na face abaxial, (10)12-16(19) cm compr., 7-8(9) cm larg., margem inteira, revoluta, nervura mediana proeminente em ambas as faces, na face abaxial com $1 \mathrm{~mm}$ largura na base foliar, linhas translúcidas densas em toda face abaxial do limbo, visíveis em folhas jovens e adultas, nervuras secundárias não impressas na face abaxial, evidentes apenas no material desidratado; pecíolo alvo-esverdeado, 1-1,5 mm compr. Inflorescências com pedúnculo curto, 2-4 mm compr., 10-12 flores; bractéolas $0,5 \mathrm{~mm}$ compr., triangulares, tricomas curtos. Flores pentâmeras, $4-5 \mathrm{~mm}$ compr.; pedicelos 1-2 mm compr.; sépalas 1-2 $\mathrm{mm}$ compr., triangulares, tricomas curtos, esparsos, raras cavidades secretoras globosas ou ausentes; pétalas $0,3-0,4 \mathrm{~mm}$ compr., 1,5 $\mathrm{mm}$ larg., cavidades secretoras lineares; estames 2-2,2 mm compr., estaminódios $1,1-5 \mathrm{~mm}$ compr., filetes conatos, 


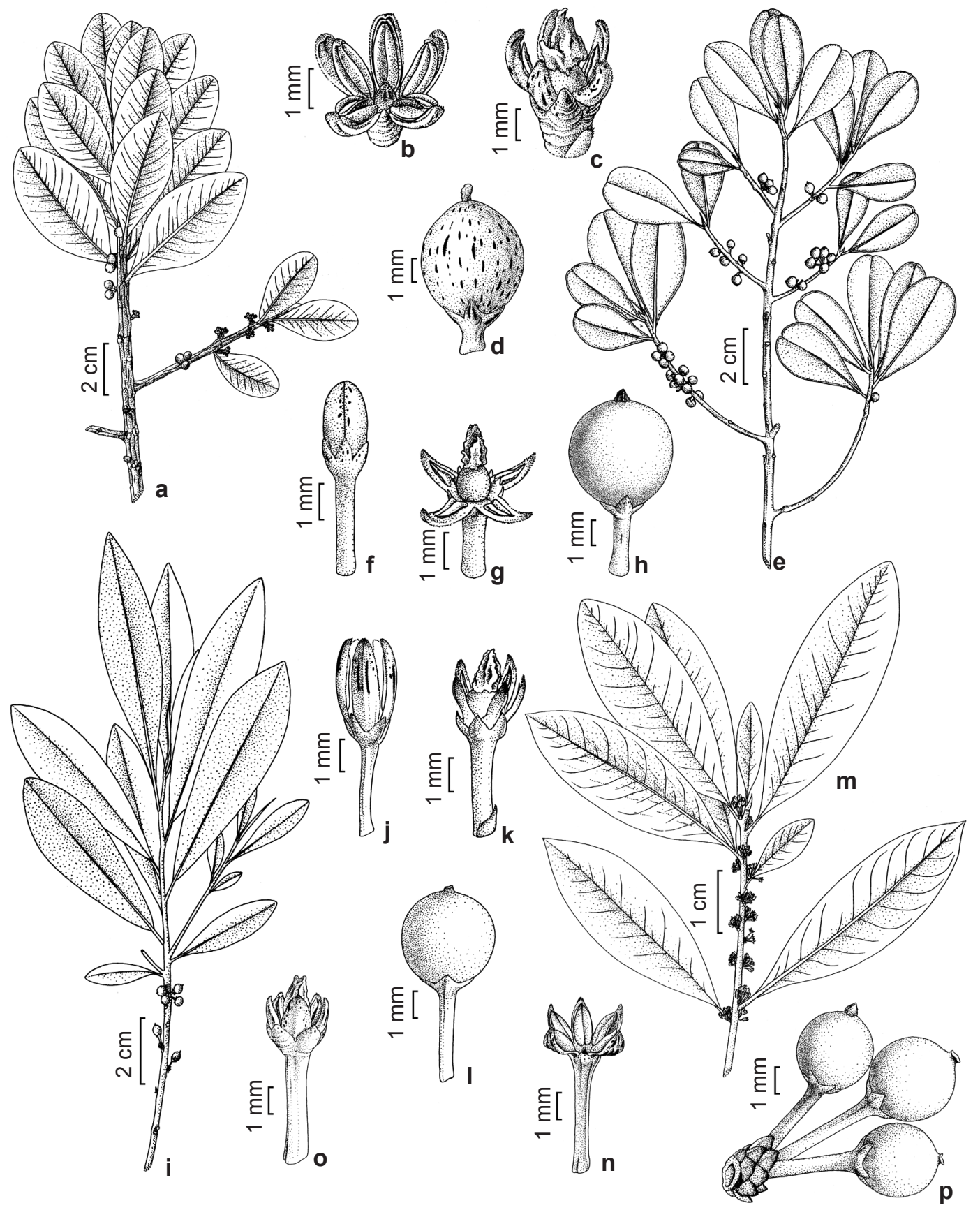

Figura 4 -a-d. Myrsine monticola. a. ramo com flores e frutos, b. flor estaminada, c. flor pistilada, d. fruto. (a,d. Salino 3605 , b. Kinoshita s.n. UEC 135119, c. Freitas 255). e-h. M. parvifolia. e. ramo com frutos, f. flor estaminada em botão, g. flor pistilada com fruto em formação, h. fruto. (e, h. Freitas 301, f. Souza 24994, g. Harley 17292). i-1. M. parvula. i. ramo com frutos, j. flor estaminada, k. flor pistilada com fruto em formação e bractéola, 1. fruto. (i, 1. Francisco s.n. FUEL 23820, j. R 11635, k. Sakai 32666). m-p. M. umbellata. m. ramo com flores, n. flor estaminada, o. flor pistilada, p. frutos e bractéolas. (m. Kollmann 2599, n. Barros 1131, o, p. Martinelli 1617)

Figure 4 - a-d. Myrsine monticola. a. branch with flowers and fruits, b. staminate flower, c. pistillate flower, d. fruit. (a,d. Salino 3605, b. Kinoshita s.n. UEC 135119, c. Freitas 255). e-h. M. parvifolia. e. branch with fruits, f. staminate bud flower, g. pistillate flower with developing fruit, h. fruit. (e, h. Freitas 301, f. Souza 24994, g. Harley 17292). i-1. M. parvula. i. branch with fruits, j. staminate flower, k. pistillate flower with developing fruit and bracteole, 1. fruit. (i, 1. Francisco s.n. FUEL 23820, j. R 11635, k. Sakai 32666). m-p. M. umbellata. m. branch with flowers, n. staminate flower, o. pistillate flower, p. fruits and bracteoles. (m. Kollmann 2599, n. Barros 1131, o, p. Martinelli 1617) 
apêndices do tubo estaminal ausentes; ovário globoso 1-1,5 mm compr., $1 \mathrm{~mm}$ larg., istilódio cônico 1-1,5 mm compr.; estigma 1-1,3 mm. Fruto globoso, 5-6 mm compr., 5-6 mm larg., pericarpo do fruto imaturo verde a castanho esverdeado, fruto maduro nigrescente, cavidades secretoras pouco visíveis.

Esta espécie é caracterizada por apresentar folhas com muitos canais secretores, em forma de densas e pequenas linhas translúcidas por todo o limbo, poucos frutos em curtos pedicelos. As flores são odoríferas e fornecem muito pólen aos insetos visitantes. Ocorrem na Bahia, Espírito Santo, Rio de Janeiro, Minas Gerais, São Paulo, e Santa Catarina.

Material selecionado: ESPÍRITO SANTO: Reserva Biológica Santa Lúcia, 30.IX,1999, V. Demuner 66 et al. (MBML, RB); MINAS GERAIS: Caratinga, Est. Biol. de Caratinga, 13.IV.1992, L.V. Costa et al. (BHCB 22356); PARANÁ: Paranaguá, Ilha do Mel, Praia do Farol, 17.IV.1987, S.M. Silva et al. 1320 (FUEL, MBM, PKDC, UEC, UPCB); RIO DE JANEIRO: Angra dos Reis, Ilha Grande, Res. Biol. Praia do Sul, Praia do Sul, 27.IX.1983, D: Araújo et al. 5690 (GUA); SANTA
CATARINA: Araquari, Barro do sul, restinga, 9.I.1953, Reitz et al. 5151 (HBR, MBM, IHN); SÃO PAULO: Cananéia, Res. Biol. Ilha do Cardoso, V.2000, M.F. Freitas et al. 303, 304 (UEC, RB);

23. Myrsine villosissima Mart, Fl. Beibl. ser. 2, 24:18.1841. Tipo: Mart. Herb. Fl. Bras. 258. Brasil, São Paulo, XII.1817, Martius (lectótipo, M)

Fig. 5e-h

Arbustos 1,-1,5(4) m alt, ramos terminais $1 \mathrm{~mm}$ diâmetro, pilosos, ferrugíneos. Folhas membranáceas, pilosas, lisas, ovadas, ápice agudo a acuminado, base obtusa, não revoluta na face abaxial, (3)4-7 cm compr., (1)1,5-2,5 cm larg., margem inteira a levemente crenada, nervura mediana proeminente em ambas as faces, na face inferior com $1 \mathrm{~mm}$ largura na base foliar, linhas translúcidas não visíveis, nervuras secundárias evidentes em ambas as faces; pecíolo alvoesverdeado, piloso, 1-2 mm compr. Inflorescências com pedúnculo curto, $1 \mathrm{~mm}$ compr.;4-5 flores, bractéolas $1 \mathrm{~mm}$ compr., triangulares, tricomas longos; Flores pentâmeras, raro tetrâmeras, 4-5

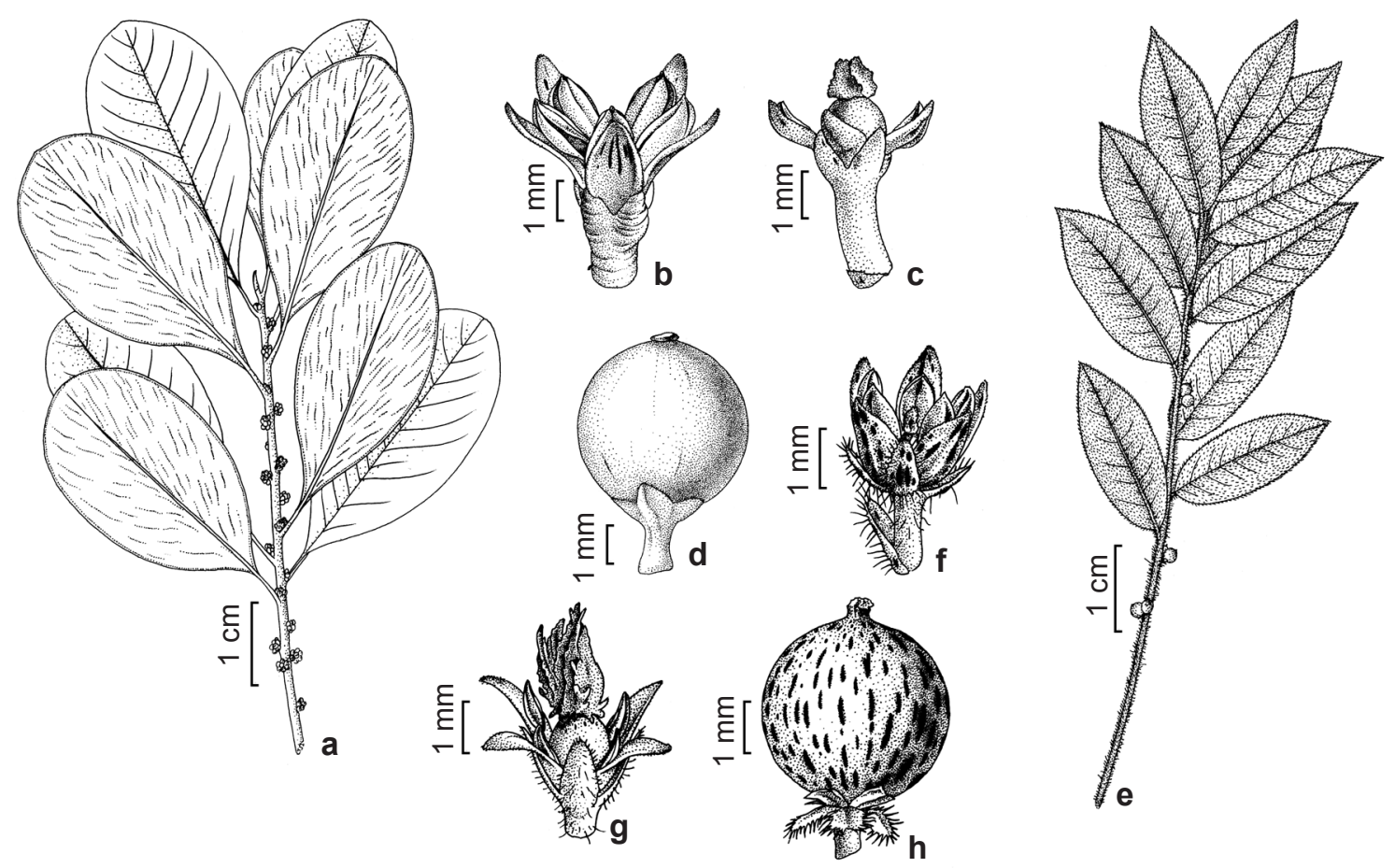

Figura 5 - a-d. Myrsine venosa. a. ramo com botões, b. flor estaminada, c. flor pistilada com fruto em formação, d. fruto. (a. Silva 1320, b. Freitas 304, c, d. Demuner 66). e-h. M. villosissima. e. ramo com frutos, f. flor estaminada com bractéola, g. flor pistilada, h. fruto. (e, h. Rossi 1552, f. Freitas 309, g. Leoni 3729).

Figure 5 - a-d. Myrsine venosa. a. branch with buds, b. staminate flower, c. pistillate flower with developing fruit, d. fruit. (a. Silva 1320, b. Freitas 304, c, d. Demuner 66). e-h. M. villosissima. e. branch with fruits, f. staminate flower with bracteole, g. pistillate flower, h. fruit. (e, h. Rossi 1552, f. Freitas 309, g. Leoni 3729). 
mm compr.; pedicelos 1,5-2 mm compr., glabros com tricomas somente na base das sépalas; sépalas 1,5-2 mm compr., ovado-lanceoladas, tricomas longos, densos, cavidades secretoras elípticas em toda sépala ou apenas na base; pétalas 3-3,5 mm compr., $1 \mathrm{~mm}$ larg., pouco pilosas; cavidades secretoras globosas e elípticas pouco visíveis, lineares ausentes; estames e estaminódios 1-2 mm compr., filetes conatos, apêndices do tubo estaminal presentes; ovário globoso e pistilódio cônico $1 \mathrm{~mm}, 1 \mathrm{~mm}$ de larg; estigma $2 \mathrm{~mm}$. Fruto globoso, 3-4 mm compr., 2-3 mm larg., pericarpo do fruto imaturo verde, cavidades secretoras visíveis.

Representada por arbustos ramificados com folhas membranáceas, muito pilosas. Os tricomas no ápice dos ramos jovens são esverdeados passando a ferrugíneos. Ocorrem em Minas Gerais, Rio de Janeiro e São Paulo.

Material selecionado: MINAS GERAIS: Ouro Preto, Camarinhas, X.2000, M. F. Freitas et al. 309 (UEC, RB); Parque Nacional do Caparaó, Alto do Caparó, VIII.1997, L. Leoni 3729 (RB). RIO DE JANEIRO: Itatiaia, Pq. Nacional de Itatiaia, km. 13, 1.II.1939, L. Lanstyak 318 (RB); SÃO PAULO: São Jose do Barreiro, Pq. Nac. Serra da Bocaina, trilha para a Cachoeira de Santo Isidro, 16.VII.1994, L. Rossi et al. 1552 (SP, IAC, UEC).

\section{Agradecimentos}

Ao CNPq, a bolsa de doutorado concedida à primeira autora; aos curadores dos herbários citados; às instituições CEPEC, IAC, JBRJ, UEL, UFPO, UFU, UNESP (campus de Assis) e UNICAMP, bem como a todos os pesquisadores e técnicos que auxiliaram nas pesquisas de campo. A Eduardo Kickhofel, a confecção das ilustrações. Aos revisores, as sugestões ao texto. Ao Departamento de Biologia Vegetal da Universidade Estadual de Campinas e ao Instituto de Pesquisas Jardim Botânico do Rio de Janeiro, o suporte para o desenvolvimento deste trabalho.

\section{Referências}

Aublet, J.B.C.F. 1775. Histoire des plantes de la Guiane Françoise. Didot, London \& Paris. 976p, 392 pl.

Augusto, I. 1946. Myrsináceas: Flora do Rio Grande do Sul. Ed. Imprensa Oficial, Porto Alegre. Pp. 30-35. Burkart, A, \& al. 1979. Myrsinaceae. In: Burkart, A. Flora Ilustrada de Entre Ríos. Dicotiledóneas Metaclamídeas: Primulales, Plumbaginales, Ebenales, Contortales, Tubiflorales, Callitrichales, Plantaginales. Vol 6, parte 5. Ed. Coleccion cientifica, Instituto National de tecnologia Agropecuaria,
Buenos Aires. Pp 9-13.Carvalho, P.E.R. 1994. Espécies florestais brasileiras. Recomendações silviculturais, potencialidades e uso da madeira. Embrapa - CNDF/SPI, Brasília. 640p.

De Candolle, A.P. 1834. Revue de la famille des Myrsineés. Annales des sciences naturelles. Botanique 2: 285-301.

De Candolle, A.P. 1837. A review of the natural order Myrsineae. Transactions of the Linnean Society of London 12: 95-138.

De Candolle, A.P. 1841a. Second mémoire sur la famille des Myrsineacées. Annales des sciences naturelles. Botanique 16: 65-97.

De Candolle, A.P. 1841b. Troisième mémoire sur la famille des Myrsineacées. Annales des sciences naturelles. Botanique 16: 129-176.

De Candolle, A.P. 1844. Myrsinaceae. In: Candolle, A. de, Prodromus Systematis Naturalis Regni Vegetabilis 8:75-140.

Edwall, G. 1905. Família Myrsinaceae. In: Flora Paulista. Commissão Geographica e Geológica de São Paulo 15: 1-45.

Fonnegra-Gómez, R.J. \& Jung-Mendacolli, S.L. 1985. Uma nova combinação para o gênero Ctenardisia Ducke (Myrsinaceae): C. stenobotrya (Standl.) Fonnegra et Jung-Mendaçolli. Hoehnea 12:31-33.

Fosberg, F.R. \& Sachet, M. 1975. Polynesian plant studies. 1-5. Smithsonian Contributions to Botany 21:1-25.

Fosberg, F.R. \& Sachet, M. 1980. Systematics studies of Micronesian plants. Smithsonian Contributions to Botany 45:1-40.

Freitas, M.F. 2003. Estudos taxonômicos das espécies de Myrsine L. (Myrsinaceae) nas regiões sul e sudeste do Brasil. Tese de Doutorado. Universidade de Campinas, Campinas. 235p.

Freitas, M.F. 2012. Primulaceae. In: Vibrans, A.C.; Sevegnani, L.; Gasper, A.L. \& Lingner, D.V. (eds.) Inventário Florístico Florestal de Santa Catarina. Vol. 1. Editora da FURB, Blumenau. Pp 307-309.

Freitas, M.F. \& Carrijo, T.T. 2012. Myrsinaceae. In: Jacobi, C.M. \& Carmo, F.F. Diversidade florística nas cangas do Quadrilátero Ferrífero. Código Editora, Belo Horizonte. Pp. 152-153.

Freitas, M.F. \& Kinoshita, L.S. 2004. New combinations of brazillian Myrsine (Myrsinaceae). Bradea 10:1-8.

Freitas, M.F. \& Kinoshita, L.S. 2005. Novas espécies de Myrsine L. (Myrsinaceae) para o Brasil. Rodriguésia 56: 67-72.

Freitas, M.F. \& Carrijo, T.T. 2008. A família Myrsinaceae nos contrafortes do Maciço da Tijuca e entorno do Jardim Botânico do Rio de Janeiro. Rodriguésia 59: 813-28.

Freitas, M.F. \& Carrijo, T.T. 2009a. Myrsinaceae. In: Giulietti, A.M.; Silva, J.M.C.; Rapini, A.; Queiroz, L.P. \& Andrade, M.J.G. (orgs.). Plantas Raras do 
Brasil.Conservação Internacional do Brasil, Belo Horizonte. 288p.

Freitas, M.F.; Carrijo, T.T. 2009b. Myrsinaceae. In: Stehmann, J.R.; Forzza, R.C.; Sobral, M., Salino, A. \& Kamino, L.H.Y. (eds.) Plantas de Floresta Atlântica. Jardim Botânico do Rio de Janeiro, Rio de Janeiro. Pp. 350-351.

Freitas, M.F. \& Carrijo, T. 2014a. Primulaceae. Catálogo das espécies de plantas vasculares e briófitas do Estado do Rio de Janeiro. Instituto de Pesquisas Jardim Botânico do Rio de Janeiro. Disponível em $<$ http://florariojaneiro.jbrj.gov.br>. Acesso em 10 julho 2014.

Freitas, M.F. \& Carrijo, T.T. 2014b. Primulaceae. Lista de Espécies da Flora do Brasil. Jardim Botânico do Rio de Janeiro. Disponível em <http://florariojaneiro. jbrj.gov.br>. Acesso em 10 julho 2014.

Freitas, M.F., Carrijo, T. \& Bernacci, L.C. 2010. Myrsinaceae. In: Forzza, R. et al. 2010. Catálogo de plantas e fungos do Brasil. Vol. 2. Instituto de Pesquisas Jardim Botânico do Rio de Janeiro, Rio de Janeiro. Pp. 297-1301.

Freitas, M.F.; Carrijo, T.T.; São Leão, L.C. \& Kinoshita, L.S. 2009. Flora da Serra do Cipó: Myrsinaceae. Boletim de Botânica da Universidade de São Paulo 27: 259-267.

Gottlieb, R.O. \& Salatino, A. 1987. Função e evolução de óleos essenciais e de suas estruturas secretoras. Ciencia e Cultura 39: 707-716.

Harvey, Y.B. \& Pipoly III, J.J. 1995. Myrsinaceae. In: Stannard, B.L. Flora of the Pico das Almas. Chapada Diamantina - Bahia, Brazil. Royal Botanical Garden, Kew. Pp. 487-491.

Holmgren, P. K.; Holmgren, N.H. \& Barnett, L.C. 1990. Index Herbariorum. The herbaria of the world. Vol. 1. New York Botanical Garden, New York. 633p.

Imkhanitskaya, N.N. 1996. Type specimens of Myrsinaceae in the Herbarium of Komarov Botanical Institute (St. Petesburg, LE). 5. Neotropical taxa of the genera Geissanthus - Weigeltia. Botanicheskii Zhurnal 81: 22-31.

Jackes, B.R. 2005. Revision of Myrsine (Myrsinaceae) in Australia. Australian Systematic Botany 18:399438.

Joly, A.B. \& Jung, S.L. 1978. Cybianthus coronatus Joly et Jung sp.n. (Myrsinaceae): uma nova espécie da Serra do Cipó, Minas Gerais, Brasil. Hoehnea 7: 41-46.

Jung, S.L. 1981. Flora fanerogâmica da Reserva do Parque Estadual das Fontes do Ipiranga (São Paulo, Brasil): 74-Myrsinaceae. Hoehnea 9: 88-91.

Jung-Mendaçolli, S.L. 2009. Myrsinaceae. In: Cavalcanti, T.B. \& Batista, M.F. Flora do Distrito Federal, Brasil. Vol. 7. Embrapa Recursos Genéticos e Biotecnologia, Brasília. Pp. 229-247.

Jung-Mendaçolli, S.L. \& Bernacci, L.C. 1997a. Rapanea hermogenesii Jung-Mendaçolli \& Bernacci
(Myrsinaceae): uma nova espécie da Mata Atlântica, Brasil. Boletim de Botânica da Universidade de São Paulo 16: 31-35.

Jung-Mendaçolli, S.L. \& Bernacci, L.C. 1997b. Flora Fanerogâmica da Ilha do Cardoso (SP, Brasil): Myrsinaceae. In: Melo, M.M.R.F.; Barros, F.; Chiea, S.A.C.; Kirizawa, M.; Jung-Mendaçolli, S.L. \& Wanderley, M.G.L. (Eds). Flora Fanerogâmica da Ilha do Cardoso. Vol. 5. Instituto de Botânica, São Paulo. Pp 81-98.

Jung-Mendaçolli, S.L. \& Bernacii, L.C. 1997 c. Myrsinaceae. In: Marques, M.C.M. Mapeamento da cobertura vegetal e listagem das espécies ocorrentes na APA Cairuçú, Mun. Parati, RJ. Série estudos e contribuições. Vol. 13. Jardim Botânico do Rio de Janeiro, Rio de Janeiro. 72p.

Jung-Mendaçolli, S.L. \& Bernacci, L.C. 2000. Considerações taxonômicas e novas combinações em Ardisia Swartz (Myrsinaceae) do sudeste do Brasil. Acta Botânica Brasílica 14: 243-249.

Jung-Mendaçolli, S.L. \& Bernacci, L.C. 2001. Myrsinaceae da APA de Cairuçú, Parati, Rio de Janeiro, Brasil. Rodriguésia 52: 49-64.

Jung-Mendaçolli, S.L.; Bernacci, L.C. \& Freitas, M.F. 2005. Myrsinaceae In: Wanderley, M.G.L.; Shepherd, G.J.; Melhem, T.S. \& Giulietti, A.M. (eds.) Flora Fanerogâmica do Estado de São Paulo. Vol. 4. Instituto de Botânica, São Paulo. Pp. 279300.

Klein, R. M. 1980. Ecologia da flora e vegetação do Vale do Itajaí. Sellowia 32: 164-369.

Linnaeus, C. 1753. Species Plantarum. Vol. 1. Ed. Imprensis Laurentii Salvii. Holmiae, Stockolm. $560 \mathrm{p}$.

Lorenzi, H. 1992. Árvores brasileiras. Manual de identificação e cultivo de plantas arbóreas nativas do Brasil. Editora Plantarum Ltda, São Paulo. 352p.

Lorenzi, H. 2009. Árvores brasileiras. Manual de identificação e cultivo de plantas arbóreas nativas do Brasil. Vol. 3. Ed. Plantarum Ltda, São Paulo. 384p.

Lundell, C.L. 1966. Myrsinaceae. In: Standley, P.C. \& Williams, L.O. Flora of Guatemala. Fieldiana 24: 135-200.

Lundell, C.L. 1971. Flora of Panama: Myrsinaceae. Annals of the Missouri Botanical Garden 58: 285353.

Lundell, C.L. 1981. Neotropical Myrsinaceae - IV. Phytologia 48: 137-142.

Lundell, C.L. 1984. Neotropical Myrsinaceae - XVII. Phytologia 56: 413-418.

Macbride, J.F. 1959. Flora of Peru: Myrsinaceae. Field Museum of Natural History, Botanical series 13(5): 163-203.

Madrigal, R.V.; Spencer, G.F.; Plattner, R.D. \& Smith, C.R. 1977. Alkyl - and alkenylresorcinols in Rapanea laetevirens seed lipds. Lipids 12: 402-406. 
Martius, C.F.P. 1841. Herbarium Florae Brasiliensis. Flora 24 (2 Beibl):1-112.

Mez, C. 1902. Myrsinaceae. In: Engler, H.G.A. Das Pflanzenreich. Berlin, Wilhelm Engelmann, 9 (236):1-437.

Miquel, F.A.G. 1856. Myrsineae. In: Martius, C.F.P.; Eichler, A.G. \& Urban, I. Flora Brasiliensis. 10: 269-338, est.24-59.

Otegui, M. 1994. Occurence of perforated ray cells and ray splitting in Rapanea laetevirens and $R$. lorentziana (Myrsinaceae). IAWA Journal 15: 257-263.

Otegui, M. 1998. Sinopsis del género Myrsine L. (Myrsinaceae) en el Cono Sur de América del Sur. Candollea 53: 133-157.

Oteguii, M. \& Cocucci, A. 1998. Flower morphology and biology of Myrsine laetevirens, structural and evolutionary implications of anemophily in Myrsinaceae. Nordic Journal of Botany 19: 71-85.

Otegui, M. \& Maldonado, S. 1998. Embriological features and bacterial transmission to gynoecium and ovule in Myrsine laetevirens (Myrsinaceae). Acta Botanica Neerlandica 47: 185-194.

Otegui, M.; Maldonado, S.; Lima, C. \& De Lederkremer, R.M. 1998a. Histological and chemical characterization of Myrsine laetevirens seed. International Journal of Plant Sciences 159: 762-772.

Otegui, M.; Maldonado, S.; Lima, C. \& De Lederkremer, R.M. 1998b. Development of the endosperm of Myrsine laetevirens (Myrsinaceae). I. Cellularization and depositon of cell wall storage carbohydrates. International Journal of Plant Sciences 160: 491-500.

Otegui, M.; Maldonado, S.; Lima, C. \& De Lederkremer, R.M. 1999. Development of the endosperm of Myrsine laetevirens (Myrsinaceae). II. Formation of protein and lipid bodies. International Journal of Plant Sciences $160: 501-509$.

Otegui, M.; Gaspar, M.L.; Maldonado, S.; Varetti, E.L. \& Pollero, R. 1997. Studies on tissues associated to hydroxybenzoquinone secretion in Myrsine laetevirens (Myrsinaceae). Nordic Journal of Botany 18: 447-459.

Pineschi, R.B. 1990. Aves como dispersoras de sete espécies de Rapanea (Myrsinaceae) no maciço do Itatiaia, estados do Rio de Janeiro e Minas Gerais. Ararajuba 1: 73-78.

Pipoly, J.J. 1991. Systematic studies in the genus Myrsine L. in Guyana. Novon 1: 204-210.

Pipoly, J.J. 1992a. Notes on the genus Myrsine (Myrsinaceae) in Peru. Novon 2: 392-407.

Pipoly, J.J. 1992b. Estudios en el género Myrsine (Myrsinaceae) de Colombia. Caldasia 17: 3-10.
Pipoly, J.J. 1996. Contributions toward a new flora of the Philippines: I. A synopsis of the genus Myrsine (Myrsinaceae). Sida 17: 115-162.

Ricketson, J.M. 2013. Nomenclatural transfers in the pantropical genus Myrsine (Myrsinaceae). Novon 22: 468-472.

Ricketson, J.M. \& Pipoly, J.J. 1997. Nomenclatural notes and synopsis of the genus Myrsine (Myrsinaceae) in Mesoamerica. Sida 17: 579-589.

Ricketson, J.M. \& Pipoly, J.J. 1999. Myrsine luae (Myrsinaceae), a new species from Brazil. Sida 18: 747-750.

Siminski, A.; Mantovani, M.; Reis, M.S. \& Fantini, A.C. 2004. Sucessão florestal secundária no município de São Pedro de Alcântara, litoral de Santa Catarina: estrutura e diversidade. Ciência Florestal, Santa Maria 14(1): 21-33.

Siqueira, J.C. 1987. Considerações taxonômicas sobre as espécies do gênero Rapanea Aublet (Myrsinaceae) ocorrentes no Rio Grande do Sul. Pesquisas Botânica. 38: 147-156.

Siqueira, J.C. 1993. O gênero Rapanea Aublet (Myrsinaceae) na região serrana do Estado do Rio de Janeiro: aspectos taxonômicos e ecológicos das espécies. Pesquisas Botânica 44: 41-52.

Sleumer, H. 1986. A revision of the genus Rapanea Aubl. (Myrsinaceae) in New Guinea. Blumea 31: 245-269.

Smith, A.C. 1973. Studies of Pacific Island plants XXV. Myrsinaceae of the Fijian Region. Journal of the Arnold Arboretum 54: 1-292.

Smith, A.C. 1981. Myrsinaceae. In: Smith, A.C. Flora Vietensis Nova. Vol. 2. Pacific Tropical Garden, Hawaii. Pp. 782-10.

Smith, L.B. \& Downs, R.J. 1957. Resumo preliminar das Mirsináceas de Santa Catarina. Sellowia 8: 237-248.

Ståhl, B. \& Anderberg, A.A. 2004. Myrsinaceae. In: Kubtski, K. (ed.) The families and genera of vascular plants. VI. Flowering Plants Dicotyledons. Celastrales, Oxalidales, Rosales, Cornales, Ericales. Springer, Berlin. Pp. 266-281.

Stearn, W.T. 1969. A synopsis of Jamaican Myrsinaceae. Bulletin of the British Museum (Natural History). Botany series 18: 884-900.

Stevens, P.F. (2001 onwards). Angiosperm Phylogeny Website. Available in <http://www.mobot.org/ MOBOT/research/APweb/> . Acess on 12 july 2012.

Valdés, C.M. 2000. New species of Ardisia and Myrsine (Myrsinaceae) from Cuba. Willdenowia 33: 173178.

Valdés, C. M. 2002. La Myrsinaceae R. Br. em Cuba. Tesis de Doctor. Universidad de La Habana, Cuba. $100 \mathrm{p}$. 